\title{
Neuromodulation of astrocytic K+ clearance
}

Alba Bellot-Saezı, Orsolya Kékesi1, Yuval Ben-Abu3, John W. Morley1 and Yossi Buskila1,2*

1. School of Medicine, Western Sydney University, Campbelltown, NSW 2560, Australia.

2 International Centre for Neuromorphic Systems, The MARCS Institute, Western Sydney

University, Penrith, NSW 2751, Australia

3 Projects and Physics Section, Sapir Academic College, D.N. Hof Ashkelon 79165, Israel

*Corresponding author:

Yossi Buskila, School of Medicine, Western Sydney University, Campbelltown, NSW 2560, Australia,+61468328301, Y.buskila@westernsydney.edu.au

Significance statement: Neuromodulators are known to mediate changes in network oscillatory behaviour and thus impact on brain states. In this study we show that certain neuromodulators directly affect distinct stages of astrocytic $\mathrm{K}+$ clearance, promoting neuronal excitability and network oscillations through parallel activation of both neurons and astrocytes, thus establishing a synergistic mechanism to maximise the synchronous network activity. 


\begin{abstract}
Potassium homeostasis is a fundamental requirement for normal brain function. Therefore, effective removal of excessive $\mathrm{K}+$ accumulation from the synaptic cleft during neuronal activity is paramount. Astrocytes, one of the most common subtype of glial cells in the brain, play a key role in $\mathrm{K}+$ clearance from the extracellular milieu using various mechanisms, including uptake via Kir channels and the $\mathrm{Na}+\mathrm{K}+$ ATPase, and spatial buffering through the astrocytic gap-junction coupled network. Recently we showed that alterations in the concentrations of extracellular potassium $\left([\mathrm{K}+]_{0}\right)$ or impairments of the astrocytic clearance mechanism effect the resonance and oscillatory behaviour of both individual and networks of neurons recorded from C57/BL6 mice of both sexes. These results indicate that astrocytes have the potential to modulate neuronal network activity, however the cellular effectors that may affect the astrocytic $\mathrm{K}+$ clearance process are still unknown. In this study, we have investigated the impact of neuromodulators, which are known to mediate changes in network oscillatory behaviour, on the astrocytic clearance process. Our results suggest that some neuromodulators (5-HT; NA) affect astrocytic spatial buffering via gap-junctions, while others (DA; Histamine) affect the uptake mechanism via Kir channels. These results suggest that neuromodulators can affect network oscillatory activity through parallel activation of both neurons and astrocytes, establishing a synergistic mechanism to recruitment of neurons into ensamble of networks to maximise the synchronous network activity.
\end{abstract}




\section{INTRODUCTION}

Animal survival is highly dependent on their ability to adapt to the changing environment. To do so, animals are constantly switching between behavioral states, which are correlated to different network oscillations. We recently showed that local alterations in the extracellular $\mathrm{K}_{+}$ concentration $\left(\left[\mathrm{K}_{+}\right]_{\mathrm{o}}\right)$ can affect the oscillatory activity of neuronal networks (Buskila et al., 2019) and that specific impairments of the astrocytic clearance mechanism can affect the resonance and oscillatory behaviour of neurons both at single cell and network levels (BellotSaez et al., 2018), implying that astrocytes can modulate neuronal network activity. However, the cellular and molecular mechanisms that affect this clearance process by astrocytes are still unknown.

Historically, network oscillations were considered to be highly affected by neuromodulation(Lee \& Dan, 2012), and previous studies indicated an essential role for neuromodulators in mediating the shift between different behavioural states. However, we still know little about the circuitry involved in this neuromodulation, specifically at the cellular level.

Cortical astrocytes found to express a wide variety of receptors for different neuromodulators, including Acetylcholine (Ach, nicotinic $\alpha / \beta$ and metabotropic M1-4)(Oikawa et al., 2005; Amar et al., 2010), Histamine (H1-3)(N. Inagaki, H. Fukui, Y. Taguchi, N.P. Wang, A. Yamatodani, 1989), Serotonin $\left(5-\mathrm{HT}_{1,2,5,6,7)}\right.$ (Hirst et al., 1998), Noradrenaline (NA, $\alpha_{1,2-}$

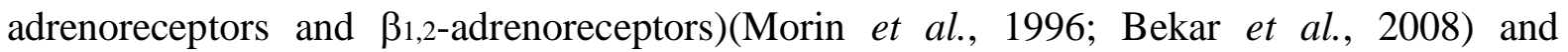
Dopamine (DA, D1-5)(Khan et al., 2001; Wei et al., 2018), which evoke [Ca2+]i increases that affect astrocytic function. For instance, Histamine leads to astrocytic [Ca2+]i increases in vitro (Jung et al., 2000) and mediates the upregulation of the glutamate transporter 1 (GLT-1) through astrocytic $\mathrm{H}_{1}$ receptors, leading to reduced extracellular glutamate levels (Fang et al., 2014) and thus playing a neuroprotective role against excitotoxicity. Similar to Histamine, NA (Ding et al., 2013; Schnell et al., 2016; Nuriya et al., 2017), DA (Vaarmann et al., 2010; Bosson et al., 2015; Jennings et al., 2017), 5-HT (Blomstrand et al., 1999; Sandén et al., 2000; Schipke et al., 2011) and ACh (Araque et al., 2002; Oikawa et al., 2005; Perea, 2005) also elicit $[\mathrm{Ca} 2+]$ i elevations in astrocytes, and a recent study showed that superfusion of a cocktail containing these neuromodulators triggered a transient increase in the $\left[\mathrm{K}_{+}\right]_{\mathrm{o}}$ levels (Ding et al., 2016). 
Astrocytic $\mathrm{Ca} 2+$ signalling and glutamate clearance play an essential role in the regulation of the network activity and $\mathrm{K}+$ homeostasis, which ultimately affects neuronal excitability underlying network oscillations (Wang Fushun et al., 2012; Ding et al., 2016). Recently, Ma et al. (2016) (Ma et al., 2016) showed that neuromodulators can signal through astrocytes by affecting their $\mathrm{Ca} 2+$ oscillations to alter neuronal circuitry and consequently behavioural output. In line with these observations, Nedergaard's group further demonstrated that bath application of neuromodulators to cortical brain slices increased $\left[\mathrm{K}_{+}\right]_{\mathrm{o}}$ regardless of synaptic activity (Ding et al., 2016), suggesting that increased $\left[\mathrm{K}_{+}\right]_{\mathrm{o}}$ could serve as a mechanism to maximize the impact of neuromodulators on synchronous activity and recruitment of neurons into networks.

In this study, we have investigated (i) which neuromodulators can affect astrocytic $\mathrm{K}_{+}$ clearance mechanisms (including $\mathrm{K}_{+}$uptake through $\mathrm{K}_{\text {ir}} 4.1$ channels and $\mathrm{K}_{+}$spatial buffering via gap junctions (GJs) to amend $\left[\mathrm{K}_{+}\right]_{\mathrm{o}}$ levels; and ii) does the impact of the different neuromodulators depend on $\left[\mathrm{K}_{+}\right]_{\mathrm{o}}$ and thereby different levels of network activity?

To this end, we assessed the impact of specific neuromodulators on the astrocytic $\mathrm{K}_{+}$ clearance mechanism by measuring their influence on the $\left[\mathrm{K}_{+}\right]_{0}$ clearance time-course in acute brain slices and further assessed whether this impact was due to a direct activation of astrocytic receptors or due to indirect influence via the neural network.

\section{MATERIALS AND METHODS}

\section{Animals and slice preparation}

For this study, we used 4-8-week-old C57/BL6 mice of either sex. All animals were healthy and handled with standard conditions of temperature, humidity, twelve hours light/dark cycle, free access to food and water, and without any intended stress stimuli. All experiments were approved and performed in accordance with Western Sydney University committee for animal use and care guidelines (Animal Research Authority \#A10588).

For slice preparations, animals were deeply anesthetized by inhalation of isoflurane (5\%), decapitated, and their brains were quickly removed and placed into ice-cold physiological solution (artificial CSF, aCSF) containing (in $\mathrm{mM}$ ): $125 \mathrm{NaCl}, 2.5 \mathrm{KCl}, 1 \mathrm{MgCl}_{2}, 1.25$ $\mathrm{NaH}_{2} \mathrm{PO}_{4}, 2 \mathrm{CaCl}_{2}, 25 \mathrm{NaHCO}_{3}, 25$ glucose and saturated with carbogen $\left(95 \% \mathrm{O}_{2}-5 \% \mathrm{CO}_{2}\right.$ 
mixture; $\mathrm{pH}$ 7.4). Parasagittal brain slices (300 $\mu \mathrm{m}$ thick) were cut with a vibrating microtome (Leica VT1200S) and transferred to the BraincubatorTm (PaYo Scientific, Sydney), as reported previously (Buskila et al., 2013). The Braincubator is an incubation system that closely monitors and controls $\mathrm{pH}$, carbogen flow and temperature, as well as irradiating bacteria through a separate UV chamber (Breen \& Buskila, 2014; Cameron et al., 2016). Slices were initially incubated for $12 \mathrm{~min}$ at $35^{\circ} \mathrm{C}$, after which they were allowed to cool to $15-16{ }^{\circ} \mathrm{C}$ and kept in the BraincubatorTm for at least 30 min before any measurement (Buskila et al., 2014, 2020).

\section{Electrophysiological recording and stimulation}

The recording chamber was mounted on an Olympus BX-51 microscope equipped with IR/DIC optics and Polygon 400 patterned illuminator (Mightex). Following staining (Fluo-4 AM, SR101) and short recovery period in the BraincubatorTM, slices of somatosensory cortex were mounted in the recording chamber, for a minimum of 15 minutes, to allow them to warm up to room temperature $\left(\sim 22^{\circ} \mathrm{C}\right)$ and were constantly perfused at a rate of $2 \mathrm{ml} / \mathrm{min}$ with carbogenated aCSF.

$\left[\mathrm{K}_{+}\right]_{\mathrm{o}}$ measurements were performed in layer II/III of the somatosensory cortex, by placing the $\mathrm{K}_{+}$-selective microelectrode nearby a selected astrocyte (termed "astrocyte $\propto$ ") stained with SR101 (Figure 1A). $\mathrm{K}+$ clearance is temperature-dependent, with Q10 of 1.7 at $26{ }_{\circ} \mathrm{C}$ and 2.6 at 37oC, mainly due to $\mathrm{Na}+\mathrm{K}+$ ATPase activity (Ransom et al., 2000a). Due to the absence of a selective blocker for astrocytic $\mathrm{Na}+\mathrm{K}+$ ATPase, and our interest in assessing $\mathrm{K}+$ uptake into astrocytes via Kir channels, these measurements were performed at room temperature $(22 \mathrm{C})$, when $\mathrm{Na}+\mathrm{K}+$ ATPase activity is fairly low. Various $\mathrm{KCl}$ concentrations, corresponding to low $(\sim 5 \mathrm{mM})$, high $(\sim 15 \mathrm{mM})$ and excessive $(\sim 30 \mathrm{mM})$, were added to physiological aCSF and locally applied at a constant distance $(\sim 10 \mu \mathrm{m})$ from the $\mathrm{K}_{+}$-selective microelectrode through a puffing pipette (tip diameter of $1 \mu \mathrm{m}$ ) for $0.1 \mathrm{sec}$, as previously described (Bellot-Saez et al., 2018). Preparation and calibration of the $\mathrm{K}_{+}$-selective microelectrodes were performed as detailed in (Deveau et al., 2005; Haack \& Rose, 2014). In short, the voltage response of the silanized $\mathrm{K}_{+}$-selective microelectrodes was calibrated before and after experiments within the experimental chamber by placing the electrode in aCSF containing different $\mathrm{KCl}$ concentrations (2.5 or "normal" aCSF, 4, 10, 15 or $30 \mathrm{mM}$ ). Once the electrode potential reached a steady state, a dose-response curve was calculated using a half-logarithmic $\left(\log _{10}\right)$ plot. $\mathrm{K}_{+}$-selective microelectrodes were considered good if the recorded voltage baseline was 
stable and the voltage response was similar before and after its experimental usage $(\sim 10 \%$ deviation). The $\mathrm{K}+$ clearance rate was calculated by dividing the concentration amplitude with the decay time $(90-10 \%)$.

To assess the impact of neuromodulators on the $\mathrm{K}_{+}$clearance rate, $\left[\mathrm{K}_{+}\right]_{\mathrm{o}}$ measurements were performed within the same brain slices before and after 5-minute bath application of different neuromodulators, including the cholinergic agonist Carbachol $(100 \mu \mathrm{M})$, Histamine dihydrochloride $(50 \mu \mathrm{M})$, Noradrenaline bitartrate $(40 \mu \mathrm{M})$, NPEC-caged-Serotonin $(30 \mu \mathrm{M})$ and NPEC-caged-Dopamine $(10 \mu \mathrm{M})$. To exclude the involvement of neuronal activity, similar experiments were conducted after perfusing slices with neuromodulators and tetrodoxin (TTX, $1 \mu \mathrm{M}$ ) for 5 additional minutes. Polygon400 illuminator (Mightex) was used to uncage NPECcaged-Serotonin and NPEC-caged-Dopamine compounds by applying focal photolysis with UV light $(\sim 360 \mathrm{~nm})$ in a selected area $(50 \mu \mathrm{m})$ which includes the surroundings of the $\mathrm{K}_{+-}$ selective microelectrode, the $\mathrm{KCl}$ puffing pipette and the selected astrocytic domain with its processes, for 1 second prior to local application of $\mathrm{KCl}$ (Figure 3A).

\section{Drugs}

All drugs were stored as frozen stock solutions and were added to aCSF just before recordings. Neuromodulators, including NA, Histamine, 5-HT and DA were purchased from Tocris Bioscience (In vitro Technologies Pty Ltd). Noradrenaline bitartrate and Histamine dihydrochloride were dissolved in water to a stock solution at final concentration of $100 \mathrm{mM}$. Carbachol (Sigma Aldrich) and caged neuromodulators, including NPEC-caged-Serotonin and NPEC-caged-Dopamine, were dissolved in DMSO to a stock solution at final concentrations of $1 \mathrm{M}$ or $100 \mathrm{mM}$, respectively. All stock solutions were stored at $-20^{\circ} \mathrm{C}$ and protected from light when required.

\section{Experimental Design and Statistical analysis}

Detailed experimental designs of $\left[\mathrm{K}_{+}\right]_{\mathrm{o}}$ measurement and $\mathrm{Ca} 2+$ signalling studies are described in Materials and Methods, and Results, including the number of animals used and cells included in the analyses. These numbers were based on our previous studies and standard practices in the field.

Comparrisons of $\mathrm{K}+$ clearance before and after application of a certain neuromodulator or TTX were conducted using two-tailed paired student t-test, as they were conducted on same slices and in the same region. For group comparrisons between different $\left[\mathrm{K}_{+}\right]_{\mathrm{o}}$ concentrations 
or treatments, in which different slices from different animals were used, we conducted oneway or two-way ANOVA followed by Tukey's post hoc test, according to the experimental design. Statistical comparisons were done with Prism 7 (GraphPad Software; San Diego, CA), and unless stated, data is reported as mean \pm S.E.M. Analysis of $\mathrm{K}_{+}$transient properties were performed using a custom-made MATLAB code (MathWorks). Probability values $<0.05$ were considered statistically significant.

\section{RESULTS}

\section{$K+$ clearance time course in acute brain slices}

To measure the $\left[\mathrm{K}_{+}\right]_{0}$ clearance rate, we have used custom built double-barreled $\mathrm{K}_{+-}$ selective microelectrodes, as previously described (Haack et al., 2015). Transient elevations of $\left[\mathrm{K}_{+}\right]_{\mathrm{o}}$ were mediated via local application of $\mathrm{KCl}$ at various concentrations corresponding to low $(5 \mathrm{mM})$, high $(15 \mathrm{mM})$ and excessive $(30 \mathrm{mM})\left[\mathrm{K}_{+}\right]_{\mathrm{o}}$, which correlate to different levels of network activity. K+-selective microelectrodes were placed in layer II/III of the somatosensory cortex, (close to a selected astrocyte stained with SR101 named "astrocyte $\propto$ ", Figure 1A) and were calibrated before and after each experiment, as described in Materials \& Methods.

Under control aCSF conditions, local application of $30 \mathrm{mM}, 15 \mathrm{mM}$ or $5 \mathrm{mM} \mathrm{KCl}$ led to $\left[\mathrm{K}_{+}\right]_{\mathrm{o}}$ increases of $9.19 \pm 0.65 \mathrm{mM}(\mathrm{n}=14), 4.38 \pm 0.34(\mathrm{n}=16)$ and $1.38 \pm 0.11(\mathrm{n}=15)$ respectively $(\mathrm{F}(2,42)=88.15, \mathrm{p}<0.0001$, one-way ANOVA with Tukey's post hoc test, Figure $1 \mathrm{~B}, \mathrm{C})$. The differences between the applied $\mathrm{KCl}$ concentrations and the measured $\left[\mathrm{K}_{+}\right]_{\mathrm{o}}$ concentrations (by the $\mathrm{K}+$ selective electrode located $10 \mu \mathrm{m}$ away from astrocyte $\propto$ ) were due to the dilution of the applied $\mathrm{KCl}$ solution.

The $\left[\mathrm{K}_{+}\right]_{\mathrm{o}}$ clearance rate was defined as the time it took the $\left[\mathrm{K}_{+}\right]_{\mathrm{o}}$ concentration to return to baseline levels measured before the local application of external $\mathrm{KCl}$ (90-10\% decreasing slope, Figure $1 \mathrm{~B}, \mathrm{D})$. Under control aCSF conditions, the $\left[\mathrm{K}_{+}\right]_{0}$ clearance rate was concentration-dependent, ranging from $2.02 \pm 0.14 \mathrm{mM} / \mathrm{sec}$ following local application of 30 $\mathrm{mM} \mathrm{KCl}(\mathrm{n}=14)$ and decreased to $1.09 \pm 0.09 \mathrm{mM} / \mathrm{sec}(\mathrm{n}=16)$ and $0.56 \pm 0.05 \mathrm{mM} / \mathrm{sec}(\mathrm{n}=15)$ following 15 and $5 \mathrm{mM} \mathrm{KCl}$ respectively $(\mathrm{F}(2,46)=62.03$, $\mathrm{p}<0.0001$, one-way ANOVA with 
tukey's post hoc test, Figure 1D). These results are consistant with previous study showing that the decay rate of $\left[\mathrm{K}_{+}\right]_{\mathrm{o}}$ was inversly correlated to the $\left[\mathrm{K}_{+}\right]_{\mathrm{o}}$ amplitude (Ransom et al., 2000a).

\section{Alterations in astrocytic $K+$ uptake and buffering mechanisms affect the $[K+]_{o}$ clearance rate}

We next assessed the specific impact of astrocytic $\mathrm{K}+$ clearance mechanisms, including "uptake via Kir4.1" and "spatial buffering via GJ", on the $\left[\mathrm{K}_{+}\right]_{\mathrm{o}}$ clearance rate. Bath application of $\mathrm{BaCl}_{2}(100 \mu \mathrm{M})$ that previously shown to selectively block astrocytic Kir4.1 channels and thus the uptake into astrocytes (Larsen \& Macaulay, 2014; Ma et al., 2014), significantly ( $F(1$, $83)=103.6, \mathrm{p}<0.0001$, two-way ANOVA) reduced the $\mathrm{K}_{+}$clearance rate for all $\left[\mathrm{K}_{+}\right]_{\mathrm{o}}$ tested (30 mM, 0.66 $\pm 0.07 \mathrm{mM} / \mathrm{sec}, \mathrm{n}=18 ; 15 \mathrm{mM}, 0.71 \pm 0.04 \mathrm{mM} / \mathrm{sec}, \mathrm{n}=14 ; 5 \mathrm{mM}, 0.28 \pm 0.01$ $\mathrm{mM} / \mathrm{sec}, \mathrm{n}=12 ; \mathrm{p}<0.0001$, two-way ANOVA with Tukey's post hoc test, Figure 2A-C), indicating a slower rate of $\mathrm{K}+$ removal from the extracellular space when $\mathrm{K}+$ uptake is impaired.

To selectively block $\mathrm{K}^{+}$spatial buffering through the astrocytic network, we incubated the slices with a mixture of connexin-43 (Cx43) mimetic peptides (GAP-26, 200 $\mu \mathrm{M}$ and GAP-27, $300 \mu \mathrm{M}$ ), that selectively decrease astrocytic connectivity via electrical GJs (Bellot-Saez et al., 2018). Indeed, selective blockade of $C x 43$ significantly reduced the $K+$ clearance rate $(F(1,82)$ $=58.54, \mathrm{p}<0.0001$, two-way ANOVA). However, disruption of the astrocytic connectivity had a differential impact on the $\mathrm{K}_{+}$clearance rate, as it affected $\mathrm{K}_{+}$transients only at high (15 $\mathrm{mM}, 0.81 \pm 0.04 \mathrm{mM} / \mathrm{sec}, \mathrm{n}=15$, Figure $2 \mathrm{~B})$ and excessive $(30 \mathrm{mM}, 0.71 \pm 0.08 \mathrm{mM} / \mathrm{sec}, \mathrm{n}=17$, Figure $2 \mathrm{C}$ ) $\left[\mathrm{K}_{+}\right]_{\mathrm{o}}$ levels $\left(\mathrm{p}<0.0001\right.$, two-way ANOVA with tukey's post hoc test). Low $\left[\mathrm{K}_{+}\right]_{\mathrm{o}}$ did not lead to a significant change in the $\mathrm{K}+$ clearance rate $(5 \mathrm{mM}, 0.50 \pm 0.03 \mathrm{mM} / \mathrm{sec}, \mathrm{n}=11$; $\mathrm{p}=0.84$, two-way ANOVA with tukey's post hoc test, figure $2 \mathrm{~A}$ ), confirming the hypothesis that $\mathrm{K}_{+}$uptake via the $\mathrm{Na}+\mathrm{K}_{+}$ATPase and Kir4.1 channels is the dominant process used to clear low levels of $\left[\mathrm{K}_{+}\right]_{\mathrm{o}}$ and astrocytic $\mathrm{K}_{+}$spatial buffering via GJ takes place at higher levels of network activity (Enkvist \& McCarthy, 1994). These results are also in agreement with a computational model constructed to simulate the impact of "net uptake" and spatial buffering on $\left[\mathrm{K}_{+}\right]_{\mathrm{o}}$ dynamics (Halnes et al., 2013).

\section{Neuromodulation of astrocytic K+ clearance; Serotonin (5-HT)}

Previous studies have demonstrated that astrocytes express several subtypes of serotonergic receptors across different brain areas, including the cortex, corpus callosum, brain stem, spinal cord and hippocampus (Bonhaus et al., 1995; Azmitia et al., 1996; Carson et al., 1996; Hirst et al., 1998; Sandén et al., 2000; Maxishima et al., 2001; Mahé et al., 2004). Cortical astrocytes 
have been found to express $5 \mathrm{HT}_{2} \mathrm{~b}$ receptors coupled to phospholipase A2 (PLA2) and phospholipase C (PLC)/Gq signalling cascades, whose activation leads to $\mathrm{Ca} 2+$ release from internal stores (Li et al., 2010) and stimulation of glycogenolysis (Kong et al., 2002). To test the impact of 5-HT on the K+ clearance rate, we photolyzed (50 $\mu$ m diameter; UV light) NPECcaged-Serotonin $(30 \mu \mathrm{M})$ in layer II/III of the somatosensory cortex, which include the astrocytic domain and nearby neurons (Figure 3A).

Our results show that following transient application of excessive $\mathrm{KCl}$ concentration (30 $\mathrm{mM}, \mathrm{n}=11$ ) and uncaging of 5 -HT, the $\mathrm{K}+$ clearance rate decreased to $1.33 \pm 0.14 \mathrm{mM} / \mathrm{sec}$ $(\mathrm{F}(1.295,12.95)=20.68, \mathrm{p}=0.0003$, one-way ANOVA with Tukey's post hoc test, Figure 3B, C). However, co-application of 5-HT and lower $\mathrm{KCl}$ concentrations (15 mM and $5 \mathrm{mM})$ did not affect the $\mathrm{K}+$ clearance rate significantly $(0.82 \pm 0.05 \mathrm{mM} / \mathrm{sec}, \mathrm{n}=11$ and $0.34 \pm 0.04 \mathrm{mM} / \mathrm{sec}$, $\mathrm{n}=10$ respectively; $(\mathrm{F}(1.420,14.20)=2.549, \mathrm{p}=0.1246$, one-way ANOVA, Figure 3D, $\mathrm{E}$, Supplementary table 1). Moreover, blockade of neuronal spiking activity with TTX $(1 \mu \mathrm{M})$ prior to 5-HT photolysis was comparable with the effect of 5-HT alone, suggesting that the observed alterations in the $\mathrm{K}+$ clearance rate at excessive $[\mathrm{K}+]_{\mathrm{o}}(\sim 30 \mathrm{mM})$ are independent of neuronal activity and likely due to the direct effect of 5-HT on the astrocytic spatial buffering mechanism.

\section{Dopamine (DA)}

DA receptors are classically grouped into $\mathrm{D}_{1}$-like ( $\mathrm{D}_{1}$ and $\left.\mathrm{D}_{5}\right)$ and $\mathrm{D}_{2}$-like ( $\mathrm{D}_{2}, \mathrm{D}_{3}$ and $\left.\mathrm{D}_{4}\right)$ receptors that activate opposite signalling cascades(Wei et al., 2018). While DA binding to D1like receptors promotes an increase in $3^{\prime}, 5^{\prime}$-cyclic adenosine monophosphate (cAMP) levels and the activation of protein kinase A (PKA) via adenylyl cyclase (Ac)(Zanassi et al., 1999), activation of $\mathrm{D}_{2}$-like receptors, which are coupled to PLC/inositol 1,4,5-triphosphate $\left(\mathrm{IP}_{3}\right)$ pathway, triggers $\mathrm{Ca}_{2}+$ release from internal stores and decreases cAMP levels (Khan et al., 2001).

In order to assess the overall impact of DA on the $\mathrm{K}+$ clearance rate we locally uncaged NPEC-caged-Dopamine compounds $(10 \mu \mathrm{M})$ (Castro et al., 2013), as described above for 5HT (Figure 3A). Focal photolysis of caged DA significantly reduced the $\mathrm{K}$ + clearance rate at all $[\mathrm{K}+]_{\mathrm{o}}$ concentrations tested, including $30 \mathrm{mM}(1.68 \pm 0.25 \mathrm{mM} / \mathrm{sec}, \mathrm{n}=13,(\mathrm{~F}(1.579,18.95)$ $=108.5), \mathrm{p}<0.0001$, one-way ANOVA with Tukey's post hoc test $), 15 \mathrm{mM}(1.21 \pm 0.15 \mathrm{mM} / \mathrm{sec}$, $\mathrm{n}=12,(\mathrm{~F}(2,22)=6.886, \mathrm{p}=0.0048$, one-way ANOVA with Tukey's post hoc test $)$ and $5 \mathrm{mM}$ $(0.56 \pm 0.08 \mathrm{mM} / \mathrm{sec}, \mathrm{n}=14,(\mathrm{~F}(1.58,20.54)=15.15, \mathrm{p}=0.0002$, one-way ANOVA with Tukey's 
post hoc test, Figure 4A-D, Supplementary table 2). Moreover, this effect was independent of neuronal activity, as addition of TTX $(1 \mu \mathrm{M})$ displayed the same results (Figure 4A-D).

\section{Noradrenaline (NA)}

Astrocytes express several receptors for NA, including $\alpha_{1}, \alpha_{2}$ and $\beta_{1}$-adenergic receptors, which mediate multiple processes. Activation of $\alpha_{1}$ receptors triggers the $\mathrm{PLC} / \mathrm{IP}_{3}$ signalling cascade that results in Ca2+ release from the internal stores (Duffy \& MacVicar, 1995; Ding et $a l ., 2013)$ leading to enhanced activity of protein kinase $\mathrm{C}(\mathrm{PKC})$ and the cAMP response element-binding (CREB)-dependent transcription (Carriba et al., 2012), and also exacerbates glutamate re-uptake into astrocytes through GLT-1/GLAST glutamate transporters (Alexander et al., 1997). In contrast, activation of $\alpha_{2}$ receptors in astrocytes primarly increase glycogenesis and reduces cAMP activity via the inhibitory G-protein (Gi/o), thus providing high ATP levels during periods of high demand, although under certain conditions it may permit glycogenolysis (Donnell et al., 2012). However, stimulation of astrocytic $\beta 1$-adenergic receptors activates Gproteins (Gs) which results in [Ca2+]i increases (Nuriya et al., 2017), cAMP accumulation, PKA activation and glycogenolysis (Xu et al., 2014). Moreover, activation of $\beta 1$-adenergic receptors enhance the $\mathrm{Na}+\mathrm{K}+-\mathrm{ATP}$ ase activity and thus facilitates $\mathrm{K}$ + clearance following high neuronal activity, yet this effect is abolished at high non-physiological levels of $[\mathrm{K}+]_{\mathrm{o}}$ (Hajek et al., 1996b).

Our results show that bath application of Noradrenaline bitartrate $(40 \mu \mathrm{M})$ led to a decrease of the $\mathrm{K}+$ clearance rate following local application of excessive $(30 \mathrm{mM}, 0.80 \pm 0.06 \mathrm{mM} / \mathrm{sec}$, $\mathrm{n}=15,(\mathrm{~F}(1.485,20.80)=21.12), \mathrm{p}<0.0001$, one-way ANOVA with Tukey's post hoc test $)$ or high $[\mathrm{K}+]_{\mathrm{o}}(15 \mathrm{mM}, 0.70 \pm 0.06 \mathrm{mM} / \mathrm{sec}, \mathrm{n}=16, \mathrm{~F}(1.396,20.95)=23.88, \mathrm{p}<0.0001$, one-way ANOVA with Tukey's post hoc test) regardless of neuronal activity, as the addition of TTX did not reverse this effect (Figure 5A-C). However, NA did not affect the $\mathrm{K}+$ clearance rate at low $[\mathrm{K}+]_{\mathrm{o}}(5 \mathrm{mM}, 0.42 \pm 0.04 \mathrm{mM} / \mathrm{sec}, \mathrm{n}=15 ;(\mathrm{F}(1.495,20.92)=1.423, \mathrm{p}=0.2586$, one-way ANOVA with Tukey's post hoc test, Figure 5D, Supplementary table 3), suggesting it mainly affects the $\mathrm{K}+$ spatial buffering process via gap junctions activated at high $[\mathrm{K}+]_{\mathrm{o}}$ and to less extent the uptake mechanism through Kir4.1 channels and Na/KATPase.

\section{Histamine}

Astrocytes express different types of histaminergic receptors, including $\mathrm{H}_{1}, \mathrm{H}_{2}$ and $\mathrm{H}_{3}$, which mediate multiple processes, including glutamate clearance (Fang et al., 2014) and

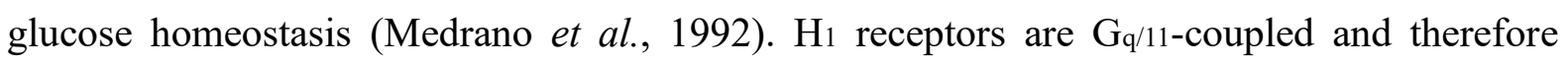


associated with PKC and PLC signalling pathways, which lead to Ca2+ release from the endoplasmic reticulum (ER) (Arbonés et al., 1988). $\mathrm{H}_{2}$ receptors are Gs-coupled and have been found to participate in glycogen breakdown and energy supply via activation of PKA and stimulation of AC (Hill, 1990). $\mathrm{H}_{3}$ receptors are Gai/o-coupled and less abundant in cortical astrocytes compared to astrocytes from other brain regions (e.g. striatum, hippocampus)(Mele \& Jurič, 2013). These receptors have been involved in mediating the inhibition of AC, while triggering PLA2, MAP kinase and PI3K/AKT signalling pathways (Mariottini et al., 2009; Jurič et al., 2016).

Bath application of Histamine dihydrochloride $(50 \mu \mathrm{M})$ significantly reduced the $\mathrm{K}_{+}$ clearance rate following local application of excessive, high and low $\mathrm{KCl}(30 \mathrm{mM}, 1.15 \pm 0.14$ $\mathrm{mM} / \mathrm{sec}, \mathrm{n}=10, \mathrm{~F}(1.013,9.116)=12.07, \mathrm{p}=0.0068$, one-way ANOVA with Tukey's post hoc test); $15 \mathrm{mM}, 0.84 \pm 0.08 \mathrm{mM} / \mathrm{sec}, \mathrm{n}=10, \mathrm{~F}(1.427,12.84)=16.60, \mathrm{p}=0.0006$, one-way ANOVA with Tukey's post hoc test); $5 \mathrm{mM}, 0.30 \pm 0.02 \mathrm{mM} / \mathrm{sec}, \mathrm{n}=11, \mathrm{~F}(1.566,15.66)=17.16, \mathrm{p}=$ 0.0002, one-way ANOVA with Tukey's post hoc test), Figure 6A-D). However, while the histaminergic impact on the $\mathrm{K}+$ clearance rate at excessive $[\mathrm{K}+]_{\text {o }}$ was not affected by neuronal activity $(30 \mathrm{mM}, 1.19 \pm 0.16 \mathrm{mM} / \mathrm{sec}, \mathrm{p}=0.22$, one-way ANOVA with Tukey's post hoc test, Figure 6B), blockade of neuronal firing with TTX increased the $\mathrm{K}+$ clearance rate at high (15 $\mathrm{mM}, \mathrm{p}=0.01$, one-way ANOVA with Tukey's post hoc test, Figure $6 \mathrm{C})$ and low $\left[\mathrm{K}_{+}\right]_{\mathrm{o}}(5 \mathrm{mM}$, $p=0.04$, one-way ANOVA with Tukey's post hoc test, Figure 6D, Supplementary table 4), indicating the involvement of neuronal activity in mediating the histaminergic effects at these lower concentrations. These results suggest that the histaminergic regulation of astrocytic $\mathrm{K}+$ clearance mechanisms is $[\mathrm{K}+]_{\mathrm{o}}-\mathrm{dependent}$ and involves direct and indirect activation via the neural network.

\section{Acetylcholine (ACh)}

Astrocytes express both ionotropic receptors $(\alpha, \beta)($ Oikawa et al., 2005) and muscarinic $G$ protein-coupled receptors (GPCRs) for ACh (M1-3)(Amar et al., 2010; Hirase et al., 2014). While activation of the $\mathrm{Ca} 2+-$ permeable $\alpha 7 \mathrm{nACh}$ receptor leads to [Ca2+]i elevations due to $\mathrm{Ca} 2+$ entry from the extracellular mileu (Sharma \& Vijayaraghavan, 2001), activation of M1-3 receptors in astrocytes increases [Ca2+] i via activation of $\mathrm{PLC}$, which elevates $\mathrm{IP}_{3}$ levels and promotes $\mathrm{Ca}_{2}+$ release from internal stores(Araque et al., 2002),(Kelly et al., 1996). Subsequently, astrocytic [Ca2+]i elevations induce gliotransmitter release of glutamate, ATP or 
D-serine, thereby leading to modulation of synaptic strength and transmission in both the hippocampus (Papouin et al., 2017) and the cortex (Takata et al., 2011).

To test the impact of $\mathrm{ACh}$ on the $\mathrm{K}+$ clearance rate, we bath applied slices with Carbachol $(100 \mu \mathrm{M})$, a non-specific ACh agonist that binds and activates both nicotinic and muscarinic ACh receptors (Hobson et al., 1983). However, the $\mathrm{K}+$ clearance rate was comparable between normal aCSF and Carbachol conditions for all $\left[\mathrm{K}_{+}\right]_{\mathrm{o}}$ tested, as shown in Figure 7A-D $(30 \mathrm{mM}$ $\mathrm{KCl}, 1.36 \pm 0.13 \mathrm{mM} / \mathrm{sec} ; 15 \mathrm{mM} \mathrm{KCl}, 0.97 \pm 0.09 \mathrm{mM} / \mathrm{sec} ; 5 \mathrm{mM} \mathrm{KCl}, 0.51 \pm 0.07 \mathrm{mM} / \mathrm{sec} ; \mathrm{p}>$ 0.05, One way ANOVA).

Since blockade of neuronal firing with TTX was comparable to control and Carbachol conditions $(30 \mathrm{mM} \mathrm{KCl}, 1.37 \pm 0.11 \mathrm{mM} / \mathrm{sec}, \mathrm{n}=15 ; 15 \mathrm{mM} \mathrm{KCl}, 1.06 \pm 0.10 \mathrm{mM} / \mathrm{sec}, \mathrm{n}=10 ; 5$ $\mathrm{mM} \mathrm{KCl}, 0.54 \pm 0.07 \mathrm{mM} / \mathrm{sec}, \mathrm{n}=10 ; \mathrm{p}>0.05$, One way ANOVA, Figure 7A-C, Supplementary table 5), these results suggest that $\mathrm{ACh}$ has no direct or indirect impact on $\mathrm{K}+$ clearance mechanisms.

\section{DISCUSSION}

Neuronal activity is accompanied by a transient local increase in $[\mathrm{K}+]_{\mathrm{o}}$, which must be cleared to maintain neuronal function. In the $\mathrm{CNS}, \mathrm{K}+$ homeostasis is maintained by astrocytic $\mathrm{K}+$ clearance mechanisms, including "net $\mathrm{K}+$ uptake" and $\mathrm{K}+$ "spatial buffering" to distal areas through GJs (Orkand et al., 1966), however the mechanisms that affect these clearance processes and overall $[\mathrm{K}+]_{0}$ dynamics are largly unknown.

In this study, we investigated the impact of different neuromodulators known to act on both neurons and astrocytes in the $\mathrm{K}+$ clearance process. Previous studies have demonstrated that neuromodulators, including DA (Ito \& Schuman, 2007), ACh (Kirkwood et al., 1999) and NA (O’Donnell et al., 2012) affect neuronal excitability, leading to altered network oscillations at multiple frequencies (Constantinople \& Bruno, 2011). Moreover, modulation of the cholinergic (Webster \& Jones, 1988; Dort et al., 2015; Ni et al., 2016) or monoaminergic (Monti, 1993; Monti \& Jantos, 2008; Carter et al., 2010) signalling pathways has been reported to affect neural network oscillatory dynamics underlying behavioural shifts, as happens during different phases of sleep (i.e. REM vs NREM) or between sleep and arousal states. Another key modulator of extracellular $\mathrm{K}+$ is the $\mathrm{Na}+\mathrm{K}+$ ATPase (NKA pump), which is expressed in both neurons and astrocytes, though with different subunit isoforms (Larsen et al., 2016). However, 
as there is no selective blockers for the astrocytic $\mathrm{Na}+\mathrm{K}+$ ATPase, we did not measure its direct affect, to avoid misinterpertation of the direct impact of neuromodulators on astrocytic activity.

Recently Ding and colleagues showed that application of a cocktail of neuromodulators to cortical brain slices result in an increase of $[\mathrm{K}+]_{\mathrm{o}}$, which did not involve neuronal activity (Kang et al., 2016). Moreover, different behavioural states, such as arousal and sleep that are modulated by different neuromodulators, were found to be associated with alterations in $[\mathrm{K}+]_{0}$ dynamics (Ding et al., 2016). Consequently, we hypothesized that different neuromodulators can modulate $[\mathrm{K}+]_{0}$ clearance rate by selectively activating different signalling pathways either directly (via astrocytes) or indirectly (via neurons) to increase $[\mathrm{K}+]_{\mathrm{o}}$ levels. To validate this hypothesis, we have measured the $[\mathrm{K}+]_{\text {o }}$ clearance rate following local application of $\mathrm{KCl}$ at different concentrations in the presence of the neuromodulators 5-HT, DA, NE, Histamine and ACh (Carbachol).

\section{Mechanisms that affects the $K+$ clearance rate}

Extracellular $\mathrm{K}+$ dynamics are determined by the rate of active $\mathrm{K}+$ uptake into nearby astrocytes, as well as the rate of extracellular diffusion (Gardner-Medwin, 1983). Previous reports suggested that the rate of $\mathrm{K}+$ clearance can also be affected by different factors, including temperature (Ransom et al., 2000b), ammonia (Rangroo Thrane et al., 2013), glutamate (Enkvist \& McCarthy, 1994) and pH, however, the cellular mechanisms affecting this clearance process are still largely unknown.

Among astrocytic $\mathrm{K}+$ clearance mechanisms, $\mathrm{K}$ + uptake becomes activated following low local increases in $[\mathrm{K}+]_{\mathrm{o}}(\sim 3-12 \mathrm{mM})$, mostly affecting small astrocytic networks located within close proximity to the synaptic release site, and becomes saturated at $[\mathrm{K}+]_{\mathrm{o}}$ above ceiling levels (>12 mM) (Heinemann \& Dieter Lux, 1977; Orkand, 1986). In contrast, the K+ spatial buffering process via GJ-mediated astrocytic networks is active when there is high accumulation of $\left[\mathrm{K}_{+}\right]$(Bellot-Saez et al., 2017). In that regard, agents that affect the clearance rate of low $[\mathrm{K}+]_{\mathrm{o}}(\sim 5 \mathrm{mM})$ independent of neuronal activity are likely to play a role in the modulation of astrocytic $\mathrm{K}+$ uptake mechanisms, mediated via the NKA pump and Kir4.1 channels (Hajek et al., 1996a; Butt \& Kalsi, 2006; Larsen et al., 2014), whereas compounds that affect the clearance rate of high and excessive $[\mathrm{K}+]_{\mathrm{o}}(15 \mathrm{mM}$ and $30 \mathrm{mM}$ respectively $)$ are more prone to regulate the $\mathrm{K}+$ spatial buffering process through GJs (Wallraff et al., 2006; Pannasch et al., 2011). Indeed, our results indicate that selective blockade of Kir4.1 channels affected the $[\mathrm{K}+]_{\mathrm{o}}$ clearance rate at all concentrations tested (Fig. 2), as the uptake occurs at all 
concentrations. However, selective inhibition of astrocytic GJ's decrease the clearance rate only at high and excessive $[\mathrm{K}+]_{\mathrm{o}}$ (Fig. 2), consistant with previous reports (Wallraff et al., 2006; Pannasch et al., 2011). In addition, a key result in this study is that the rate of $\mathrm{K}+$ clearance is concentration dependent and inversly correlated to the $\left[\mathrm{K}_{+}\right]_{\mathrm{o}}$ (Fig. 1). This is probably due the fact that at high concentrations, $\mathrm{K}+$ clearance is facilitated by GJ, as previously reported (Enkvist \& McCarthy, 1994; Larsen et al., 2014). A previous study specified that $\mathrm{BaCl}_{2}$ mainly affect the $[\mathrm{K}+]_{\mathrm{o}}$ peak amplitude (Larsen et al., 2014), however the amplitude was measured following high frequency stimulation that lasted for $10 \mathrm{sec}$, during which neurons constantly excert $\mathrm{K}+$ to the vicinity of the recording electrode. In comparrison, our stimulus was much shorter $(0.1 \mathrm{sec})$, and therefore allow direct measurement of the clearance rate without the impact of further $\mathrm{K}+$ increase to the extracellular fluid.

\section{Neuromodulators impact on the $[K+]$ o clearance rate}

The involvement of different neuromodulators in the regulation of network oscillations has been reported in many studies (Webster \& Jones, 1988; Monti \& Jantos, 2008; Dort et al., 2015; Ni et al., 2016), however the circuitry in which they mediate their impact remains elusive. Here we demonstrate that certain neuromodulators work in parallel on both neuronal and astrocytic networks, leading to differential impact on the $\mathrm{K}$ + clearance rate. However, while some neuromodulators (e.g. 5-HT, DA and NA) exert their activity directly via astrocytes, other neuromodulators, such as Histamine expressed a more complex involvement, in which they affect the clearance rate indirectly via neuronal activity at low concentration and directly at excessive concentration (Fig. 6).

Moreover, while ACh had no impact on the $[\mathrm{K}+]_{0}$ clearance rate at any of the concentrations tested (Fig. 7), all other neuromodulators significantly decrease the $\mathrm{K}+$ clearance rate following excessive increase of $[\mathrm{K}+]_{\mathrm{o}}$ (Fig. 3-6). In contrast, the clearance rate following a low increase of $[\mathrm{K}+]_{\mathrm{o}}$ was affected only by DA and Histamine (Fig 4B and 6B respectively), though DA affected astrocytes direcly and the histaminergic effect was mediated by neuronal synaptic activity.

Together, these results suggest that 5-HT and NA effect on the $\mathrm{K}+$ clearance rate was comparable to the impact of selective blockade of astrocytic gap junctions by $\mathrm{Cx} 43$ mimetic peptides, suggesting they affect only the spatial buffering process. In comparrison, DA and Histamine effect on the $\mathrm{K}+$ clearance rate was comparable to the impact of selective blockade of $\mathrm{Kir} 4.1$ channels by $\mathrm{BaCl}_{2}$, suggesting they affect the uptake process. However, we cannot 
exclude the possibility that DA and Histamine affect the the spatial buffering process as well, as both processes are mediating $\mathrm{K}+$ clearance under high and excessive concentrations.

Monoamines, including catecholamines (i.e. NA, DA), 5-HT and Histamine are involved in a broad spectrum of physiological functions (e.g. memory, emotion, arousal)(Cirelli \& Tononi, 2000; Lowry et al., 2005; Eckart et al., 2016), as well as in psychiatric and neurodegenerative disorders (e.g. Parkinson's disease, Alzheimer's disease, schizophrenia, depression)(Panula et al., 1997; Ray et al., 2008; Heneka et al., 2010). At the cellular level, synaptic release of neuromodulators impact membrane properties as well as intracellular signalling pathways in both neurons and glial cells (Kang et al., 2016; Ma et al., 2016), and previous reports showed that different neuromodulators can fine-tune the hyperpolarization-activated current $I h$ (Maccaferri \& McBain, 1996; Rosenkranz, 2006; Ma et al., 2007), thereby affecting membrane resonance of individual neurons, which affect the oscillatory behaviour of single neurons and their synchronization into networks (Tseng et al., 2014). However, whether this was a direct effect of the neuromodulators on neuronal activity, or indirect via astrocytic modulation was never tested.

A recent study by Ma and colleagues show that neuromodulatory signalling in Drosophila can flow through astrocytes and promote their synchrous activation (Ma et al., 2016). They further suggest that astrocyte-based neuromodulation is an ancient feature of the Metazoan nervous sytem. Moreover, Slezak and colleagues (Slezak et al., 2018) suggested that astrocytes function as multi-modal integrators, encoding visual signals in conjuction with arousal state. Our results support this concept, in which neuromodulators impact network oscillatory activity through parallal activation of both neurons and astrocytes, establishing a synergetic mechanism to maximise their impact on synchronous network activity and recruitment of neurons into networks. 


\section{REFERENCES}

Alexander GM, Grothusen JR, Gordon SW \& Schwartzman RJ (1997). Intracerebral microdialysis study of glutamate reuptake in awake, behaving rats. Brain Res; DOI: 10.1016/S0006-8993(97)00519-2.

Amar M, Lucas-Meunier E, Baux G \& Fossier P (2010). Blockade of different muscarinic receptor subtypes changes the equilibrium between excitation and inhibition in rat visual cortex. Neuroscience 169, 1610-1620.

Araque A, Martin ED, Perea G, Arellano JI \& Buno W (2002). Synaptically Released Acetylcholine Evokes Ca2+ Elevations in Astrocytes in Hippocampal Slices. J Neurosci; DOI: 20026212.

Arbonés L, Picatoste F \& García A (1988). Histamine H1-receptors mediate phosphoinositide hydrolysis in astrocyte-enriched primary cultures. Brain Res; DOI: 10.1016/00068993(88)91554-5.

Azmitia EC, Gannon PJ, Kheck NM \& Whitaker-Azmitia PM (1996). Cellular localization of the 5-HT1A receptor in primate brain neurons and glial cells.

Neuropsychopharmacology; DOI: 10.1016/S0893-133X(96)80057-1.

Bekar LK, He W \& Nedergaard M (2008). Locus coeruleus alpha-adrenergic-mediated activation of cortical astrocytes in vivo. Cereb Cortex 18, 2789-2795.

Bellot-Saez A, Cohen G, van Schaik A, Ooi L, W Morley J \& Buskila Y (2018). Astrocytic modulation of cortical oscillations. Sci Rep 8, 11565.

Bellot-Saez A, Kékesi O, Morley JW \& Buskila Y (2017). Astrocytic modulation of neuronal excitability through $\mathrm{K}+$ spatial buffering. Neurosci Biobehav Rev; DOI:

10.1016/j.neubiorev.2017.03.002.

Blomstrand F, Khatibi S, Muyderman H, Hansson E, Olsson T \& Rönnbäck L (1999). 5hydroxytryptamine and glutamate modulate velocity and extent of intercellular calcium signalling in hippocampal astroglial cells in primary cultures. Neuroscience $\mathbf{8 8}, 1241-$ 1253.

Bonhaus DW, Bach C, DeSouza a, Salazar FH, Matsuoka BD, Zuppan P, Chan HW \& Eglen RM (1995). The pharmacology and distribution of human 5-hydroxytryptamine2B (5HT2B) receptor gene products: comparison with 5-HT2A and 5-HT2C receptors. $\mathrm{Br} J$ Pharmacol; DOI: 10.1111/j.1476-5381.1995.tb14977.x.

Bosson A, Boisseau S, Buisson A, Savasta M \& Albrieux M (2015). Disruption of dopaminergic transmission remodels tripartite synapse morphology and astrocytic calcium activity within substantia nigra pars reticulata. Glia; DOI: 10.1002/glia.22777.

Breen PP \& Buskila Y (2014). Braincubator: An incubation system to extend brain slice lifespan for use in neurophysiology. In Engineering in Medicine and Biology Society (EMBC), 2014 36th Annual International Conference of the IEEE, pp. 4864-4867. 


\section{IEEE, Chicago.}

Buskila Y, Bellot-Saez A, Ke'kesi O, Cameron M \& Morley J (2020). Extending the Life Span of Acute Neuronal Tissue for Imaging and Electrophysiological Studies. In Basic Neurobiology Techniques. Springer Nature.

Buskila Y, Bellot-saez A \& Morley JW (2019). Generating Brain Waves, the Power of Astrocytes. Front Neurosci 13, 1-10.

Buskila Y, Breen PP, Tapson J, van Schaik A, Barton M \& Morley JW (2014). Extending the viability of acute brain slices. Sci Rep 4, 4-10.

Buskila Y, Morley JW, Tapson J \& van Schaik A (2013). The adaptation of spike backpropagation delays in cortical neurons. Front Cell Neurosci 7, 1-9.

Butt AM \& Kalsi A (2006). Inwardly rectifying potassium channels (Kir) in central nervous system glia: A special role for Kir4.1 in glial functions. $J$ Cell Mol Med 10, 33-44.

Cameron M, Kekesi O, Morley JW, Tapson J, Breen PP, van Schaik AAA, Buskila Y, Kékesi O, Morley JW, Tapson J, Breen PP, van Schaik AAA \& Buskila Y (2016). Calcium imaging of AM dyes following prolonged incubation in acute neuronal tissue. PLoS One; DOI: 10.1371/journal.pone.0155468.

Carriba P, Pardo L, Parra-damas A, Lichtenstein MP, Saura CA, Pujol A, Masgrau R \& Galea E (2012). ATP and Noradrenaline Activate CREB in Astrocytes via Noncanonical Ca 21 and Cyclic AMP Independent Pathways. 1344, 1330-1344.

Carson MJ, Thomas EA, Danielson PE \& Sutcliffe JG (1996). The 5-HT(5A) serotonin receptor is expressed predominantly by astrocytes in which it inhibits cAMP accumulation: A mechanism for neuronal suppression of reactive astrocytes. Glia; DOI: 10.1002/(SICI)1098-1136(199608)17:4<317::AID-GLIA6>3.0.CO;2-W.

Carter ME, Yizhar O, Chikahisa S, Nguyen H, Adamantidis A, Nishino S, Deisseroth K \& De Lecea L (2010). Tuning arousal with optogenetic modulation of locus coeruleus neurons. Nat Neurosci; DOI: 10.1038/nn.2682.

Castro LRV, Brito M, Guiot E, Polito M, Korn CW, Hervé D, Girault JA, Paupardin-Tritsch D \& Vincent P (2013). Striatal neurones have a specific ability to respond to phasic dopamine release. J Physiol; DOI: 10.1113/jphysiol.2013.252197.

Cirelli C \& Tononi G (2000). Differential expression of plasticity-related genes in waking and sleep and their regulation by the noradrenergic system. $J$ Neurosci; DOI: 20/24/9187 [pii].

Constantinople CM \& Bruno RM (2011). Effects and mechanisms of wakefulness on local cortical networks. Neuron; DOI: 10.1016/j.neuron.2011.02.040.

Deveau JST, Lindinger MI \& Grodzinski B (2005). An improved method for constructing and selectively silanizing double-barreled, neutral liquid-carrier, ion-selective 
microelectrodes. Biol Proced Online; DOI: 10.1251/bpo103.

Ding F, O'Donnell J, Thrane AS, Zeppenfeld D, Kang H, Xie L, Wang F \& Nedergaard M (2013). $\alpha 1$-Adrenergic receptors mediate coordinated Ca2+ signaling of cortical astrocytes in awake, behaving mice. Cell Calcium; DOI: 10.1016/j.ceca.2013.09.001.

Ding F, O’Donnell J, Xu Q, Kang N, Goldman N \& Nedergaard M (2016). Changes in the composition of brain interstitial ions control the sleep-wake cycle. Science (80-) 352, $550-555$.

Donnell JO, Zeppenfeld D, Mcconnell E, Pena S \& Maiken Nedergaard (2012).

Norepinephrine: A Neuromodulator That Boosts the Function of Multiple Cell Types to Optimize CNS Performance. Neurochem Res 37, 2496-2512.

Dort CJ Van, Zachs DP, Kenny JD, Zheng S, Goldblum RR, Ramos DM, Gelwan N a \& Wilson M a (2015). Optogenetic activation of cholinergic neurons in the PPT or LDT induces REM sleep. Proc Natl Acad Sci; DOI: 10.1073/pnas.1423136112.

Duffy S \& MacVicar B a (1995). Adrenergic calcium signaling in astrocyte networks within the hippocampal slice. J Neurosci; DOI: 10.1523/JNEUROSCI.15-08-05535.1995.

Eckart C, Woźniak-Kwaśniewska A, Herweg NA, Fuentemilla L \& Bunzeck N (2016). Acetylcholine modulates human working memory and subsequent familiarity based recognition via alpha oscillations. Neuroimage 137, 61-69.

Enkvist MOK \& McCarthy KD (1994). Astroglial Gap Junction Communication Is Increased by Treatment with Either Glutamate or High K + Concentration. J Neurochem 62, 489495.

Fang Q, Hu WW, Wang XF, Yang Y, Lou GD, Jin MM, Yan HJ, Zeng WZ, Shen Y, Zhang SH, Xu T Le \& Chen Z (2014). Histamine up-regulates astrocytic glutamate transporter 1 and protects neurons against ischemic injury. Neuropharmacology; DOI: 10.1016/j.neuropharm.2013.06.012.

Gardner-Medwin A. (1983). Analysis of potassium dynamics in mammalian brain tissue. $J$ Physiol 335, 393-426.

Haack N, Durry S, Kafitz KW, Chesler M \& Rose C (2015). Double-barreled and Concentric Microelectrodes for Measurement of Extracellular Ion Signals in Brain Tissue. J Vis Exp1-15.

Haack N \& Rose CR (2014). Preparation, Calibration and Application of PotassiumSelective Microelectrodes. Microelectrodes 49, 87-105.

Hajek I, Subbarao K V \& Hertz L (1996a). Acute and chronic effects of potassium and noradrenaline on $\mathrm{Na}^{+}, \mathrm{K}+$-ATPase activity in cultured mouse neurons and astrocytes. Neurochem Int 28, 335-342.

Hajek I, Subbarao KVS \& Hertz L (1996b). Acute and chronic effects of potassium and 
noradrenaline on $\mathrm{Na}+, \mathrm{K}+$-ATPase activity in cultured mouse neurons and astrocytes. Neurochem Int 28, 335-342.

Halnes G, Østby I, Pettersen KH, Omholt SW \& Einevoll GT (2013). Electrodiffusive Model for Astrocytic and Neuronal Ion Concentration Dynamics. PLoS Comput Biol; DOI: 10.1371/journal.pcbi.1003386.

Heinemann U \& Dieter Lux H (1977). Ceiling of stimulus induced rises in extracellular potassium concentration in the cerebral cortex of cat. Brain Res 120, 231-249.

Heneka MT, Nadrigny F, Regen T, Martinez-Hernandez A, Dumitrescu-Ozimek L, Terwel D, Jardanhazi-Kurutz D, Walter J, Kirchhoff F, Hanisch U-K \& Kummer MP (2010). Locus ceruleus controls Alzheimer's disease pathology by modulating microglial functions through norepinephrine. Proc Natl Acad Sci; DOI: 10.1073/pnas.0909586107.

Hill SJ (1990). Distribution, properties, and functional characteristics of three classes of histamine receptor. Pharmacol Rev.

Hirase H, Iwai Y, Takata N, Shinohara Y \& Mishima T (2014). Volume transmission signalling via astrocytes. Philos Trans R Soc B Biol Sci; DOI: 10.1098/rstb.2013.0604.

Hirst WD, Cheung NY, Rattray M, Price GW \& Wilkin GP (1998). Cultured astrocytes express messenger RNA for multiple serotonin receptor subtypes, without functional coupling of 5-HT1 receptor subtypes to adenylyl cyclase. Mol Brain Res; DOI: 10.1016/S0169-328X(98)00206-X.

Hobson JA, Goldberg M, Vivaldi E \& Riew D (1983). Enhancement of desynchronized sleep signs after pontine microinjection of the muscarinic agonist bethanechol. Brain Res; DOI: 10.1016/0006-8993(83)90424-9.

Ito H \& Schuman E (2007). Frequency-dependent gating of synaptic transmission and plasticity by dopamine. Front Neural Circuits; DOI: 10.3389/neuro.04/001.2007.

Jennings A, Tyurikova O, Bard L, Zheng K, Semyanov A, Henneberger C \& Rusakov DA (2017). Dopamine elevates and lowers astroglial $\mathrm{Ca} 2+$ through distinct pathways depending on local synaptic circuitry. Glia 65, 447-459.

Jung S, Pfeiffer F \& Deitmer JW (2000). Histamine-induced calcium entry in rat cerebellar astrocytes: Evidence for capacitative and non-capacitative mechanisms. J Physiol 527, 549-561.

Jurič DM, Kržan M \& Lipnik-Stangelj M (2016). Histamine and astrocyte function.

Pharmacol Res; DOI: 10.1016/j.phrs.2016.07.035.

Kang N, Goldman N, Nedergaard M, O’Donnell J, Xu Q \& Ding F (2016). Changes in the composition of brain interstitial ions control the sleep-wake cycle. Science (80- ) 352, $550-555$.

Kelly JF, Furukawa K, Barger SW, Rengen MR, Mark RJ, Blanc EM, Roth GS \& Mattson 
MP (1996). Amyloid beta-peptide disrupts carbachol-induced muscarinic cholinergic signal transduction in cortical neurons. Proc Natl Acad Sci U S A.

Khan ZU, Koulen P, Rubinstein M, Grandy DK \& Goldman-Rakic PS (2001). An astroglialinked dopamine D2-receptor action in prefrontal cortex. Proc Natl Acad Sci U S A; DOI: 10.1073/pnas.98.4.1964.

Kirkwood A, Rozas C, Kirkwood J, Perez F \& Bear MF (1999). Modulation of long-term synaptic depression in visual cortex by acetylcholine and norepinephrine. J Neurosci.

Kong EKC, Peng L, Chen Y, Yu ACH \& Hertz L (2002). Up-regulation of 5-HT2Breceptor density and receptor-mediated glycogenolysis in mouse astrocytes by long-term fluoxetine administration. Neurochem Res; DOI: 10.1023/A:1014862808126.

Larsen BR, Assentoft M, Cotrina ML, Hua SZ, Nedergaard M, Kaila K, Voipio J \& Macaulay $\mathrm{N}$ (2014). Contributions of the $\mathrm{Na}+\mathrm{K}+$-ATPase, NKCC1, and Kir4.1 to hippocampal $\mathrm{K}+$ clearance and volume responses. Glia 62, 608-622.

Larsen BR \& Macaulay N (2014). Kir4.1-mediated spatial buffering of KC: Experimental challenges in determination of its temporal and quantitative contribution to $\mathrm{KC}$ clearance in the brain. Channels $\mathbf{8}, 1-7$.

Larsen BR, Stoica A \& Macaulay N (2016). Managing Brain Extracellular K + during Neuronal Activity: The Physiological Role of the $\mathrm{Na}+/ \mathrm{K}+$-ATPase Subunit Isoforms. Front Physiol 7, 1-10.

Lee S \& Dan Y (2012). Neuromodulation of Brain States. Neuron 76, 209-222.

Li B, Zhang S, Li M, Hertz L \& Peng L (2010). Serotonin increases ERK1/2 phosphorylation in astrocytes by stimulation of 5-HT2B and 5-HT2C receptors. Neurochem Int; DOI: 10.1016/j.neuint.2010.04.017.

Lowry CA, Johnson PL, Hay-Schmidt A, Mikkelsen J \& Shekhar A (2005). Modulation of anxiety circuits by serotonergic systems. Stress; DOI: 10.1080/10253890500492787.

Ma B, Xu G, Wang W, Enyeart JJ \& Zhou M (2014). Dual patch voltage clamp study of low membrane resistance astrocytes in situ. Mol Brain 7, 1-12.

Ma L, Shalinsky MH, Alonso A \& Dickson CT (2007). Effects of serotonin on the intrinsic membrane properties of layer II medial entorhinal cortex neurons. Hippocampus; DOI: 10.1002/hipo.20250.

Ma Z, Stork T, Bergles DE \& Freeman MR (2016). Neuromodulators signal through astrocytes to alter neural circuit activity and behavior. Nature 17, 428-432.

Maccaferri G \& McBain CJ (1996). The hyperpolarization-activated current (Ih) and its contribution to pacemaker activity in rat CA1 hippocampal stratum oriens-alveus interneurones. J Physiol 497 ( Pt 1, 119-130.

Mahé C, Bernhard M, Bobirnac I, Keser C, Loetscher E, Feuerbach D, Dev KK \& Schoeffter 
$\mathrm{P}$ (2004). Functional expression of the serotonin 5-HT7 receptor in human glioblastoma cell lines. Br J Pharmacol; DOI: 10.1038/sj.bjp.0705936.

Mariottini C, Scartabelli T, Bongers G, Arrigucci S, Nosi D, Leurs R, Chiarugi A, Blandina P, Pellegrini-Giampietro DE \& Beatrice Passani M (2009). Activation of the histaminergic $\mathrm{H} 3$ receptor induces phosphorylation of the Akt/GSK-3 $\beta$ pathway in cultured cortical neurons and protects against neurotoxic insults. J Neurochem; DOI: 10.1111/j.14714159.2009.06249.x.

Maxishima M, Shiga T, Shutoh F, Hamada S, Maeshima T \& Okado N (2001). Serotonin 2A receptor-like immunoreactivity is detected in astrocytes but not in oligodendrocytes of rat spinal cord. Brain Res; DOI: 10.1016/S0006-8993(00)03150-4.

Medrano S, Gruenstein E \& Dimlich R V (1992). Histamine stimulates glycogenolysis in human astrocytoma cells by increasing intracellular free calcium. Brain Res.

Mele T \& Jurič DM (2013). Identification and pharmacological characterization of the histamine $\mathrm{H} 3$ receptor in cultured rat astrocytes. Eur J Pharmacol; DOI: 10.1016/j.ejphar.2013.10.028.

Monti JM (1993). Involvement of histamine in the control of the waking state. Life Sci; DOI: 10.1016/0024-3205(93)90592-Q.

Monti JM \& Jantos H (2008). The roles of dopamine and serotonin, and of their receptors, in regulating sleep and waking. Prog Brain Res; DOI: 10.1016/S0079-6123(08)00929-1.

Morin D, Sapena R, Zini R, Onteniente B \& Tillement JP (1996). Characterization of $\beta$ adrenergic receptors of freshly isolated astrocytes and neurons from rat brain. Life Sci; DOI: 10.1016/S0024-3205(96)00632-7.

N. Inagaki, H. Fukui, Y. Taguchi, N.P. Wang, A. Yamatodani HW (1989). Characterization of histamine H1-receptors on astrocytes in primary culture: [3H]mepyramine binding studies. Eur J Pharmacol 173, 43-51.

Ni KM, Hou XJ, Yang CH, Dong P, Li Y, Zhang Y, Jiang P, Berg DK, Duan S \& Li XM (2016). Selectively driving cholinergic fibers optically in the thalamic reticular nucleus promotes sleep. Elife; DOI: 10.7554/eLife.10382.

Nuriya M, Takeuchi M \& Yasui M (2017). Background norepinephrine primes astrocytic calcium responses to subsequent norepinephrine stimuli in the cerebral cortex. Biochem Biophys Res Commun; DOI: 10.1016/j.bbrc.2016.12.073.

O’Donnell J, Zeppenfeld D, McConnell E, Pena S \& Nedergaard M (2012). Norepinephrine: A neuromodulator that boosts the function of multiple cell types to optimize CNS performance. Neurochem Res; DOI: 10.1007/s11064-012-0818-x.

Oikawa H, Nakamichi N, Kambe Y, Ogura M \& Yoneda Y (2005). An increase in intracellular free calcium ions by nicotinic acetylcholine receptors in a single cultured rat cortical astrocyte. J Neurosci Res 79, 535-544. 
Orkand RK (1986). Introductory Remarks: glial-interstitial fluid exchange. Neuronal Microenviron 481, 269-272.

Orkand RK, Nicholls JG \& Kuffler SW (1966). Effect of nerve impulses on the membrane potential of glial cells in the central nervous system of amphibia. J Neurophysiol 29, 788-806.

Pannasch U, Vargová L, Reingruber J, Ezan P, Holcman D \& Giaume C (2011). Astroglial networks scale synaptic activity and plasticity. Proc Natl Acad Sci U S A 108, 84678472.

Panula P, Rinne J, Kuokkanen K, Eriksson KS, Sallmen T, Kalimo H \& Relja M (1997). Neuronal histamine deficit in Alzheimer's disease. Neuroscience; DOI: 10.1016/S03064522(97)00353-9.

Papouin T, Dunphy JM, Tolman M, Dineley KT \& Haydon PG (2017). Septal Cholinergic Neuromodulation Tunes the Astrocyte-Dependent Gating of Hippocampal NMDA Receptors to Wakefulness. Neuron; DOI: 10.1016/j.neuron.2017.04.021.

Perea G (2005). Properties of Synaptically Evoked Astrocyte Calcium Signal Reveal Synaptic Information Processing by Astrocytes. J Neurosci; DOI:

10.1523/JNEUROSCI.3965-04.2005.

Rangroo Thrane V, Thrane AS, Wang F, Cotrina ML, Smith N a, Chen M, Xu Q, Kang N, Fujita T, Nagelhus E a \& Nedergaard M (2013). Ammonia triggers neuronal disinhibition and seizures by impairing astrocyte potassium buffering. Nat Med 19, 1643-1648.

Ransom CB, Ransom BR \& Sontheimer H (2000a). Activity-dependent extracellular K+ accumulation in rat optic nerve: The role of glial and axonal $\mathrm{Na}+$ pumps. $J$ Physiol.

Ransom CB, Ransom BR \& Sontheimer H (2000b). Activity-dependent extracellular K+ accumulation in rat optic nerve: the role of glial and axonal $\mathrm{Na}+$ pumps. $J$ Physiol; DOI: 10.1111/j.1469-7793.2000.00427.x.

Ray NJ, Jenkinson N, Wang S, Holland P, Brittain JS, Joint C, Stein JF \& Aziz T (2008). Local field potential beta activity in the subthalamic nucleus of patients with Parkinson's disease is associated with improvements in bradykinesia after dopamine and deep brain stimulation. Exp Neurol; DOI: 10.1016/j.expneurol.2008.05.008.

Rosenkranz JA (2006). Dopaminergic Regulation of Neuronal Excitability through

Modulation of Ih in Layer V Entorhinal Cortex. J Neurosci; DOI:

10.1523/JNEUROSCI.4333-05.2006.

Sandén N, Thorlin T, Blomstrand F, Persson P a I \& Hansson E (2000). 5-

Hydroxytryptamine $(2 \mathrm{~B})$ receptors stimulate $\mathrm{Ca} 2+$ increases in cultured astrocytes from three different brain regions. Neurochem Int; DOI: 10.1016/S0197-0186(99)00134-5.

Schipke CG, Heuser I \& Peters O (2011). Antidepressants act on glial cells: SSRIs and 
serotonin elicit astrocyte calcium signaling in the mouse prefrontal cortex. J Psychiatr Res; DOI: 10.1016/j.jpsychires.2010.06.005.

Schnell C, Negm M, Driehaus J, Scheller A \& Hülsmann S (2016). Norepinephrine-induced calcium signaling in astrocytes in the respiratory network of the ventrolateral medulla. Respir Physiol Neurobiol; DOI: 10.1016/j.resp.2015.10.008.

Sharma G \& Vijayaraghavan S (2001). Nicotinic cholinergic signaling in hippocampal astrocytes involves calcium-induced calcium release from intracellular stores. Proc Natl Acad Sci U S A; DOI: 10.1073/pnas.071540198.

Slezak M, Kandler S, Veldhoven PP Van, Bonin V \& Holt MG (2018). Astrocytes integrate local sensory and brain-wide neuromodulatory signals. bioRxiv381434.

Takata N, Mishima T, Hisatsune C, Nagai T, Ebisui E, Mikoshiba K \& Hirase H (2011). Astrocyte Calcium Signaling Transforms Cholinergic Modulation to Cortical Plasticity In Vivo. J Neurosci 31, 18155-18165.

Tseng H, Martinez D \& Nadim F (2014). The frequency preference of neurons and synapses in a recurrent oscillatory network. J Neurosci 34, 12933-12945.

Vaarmann A, Gandhi S \& Abramov AY (2010). Dopamine induces Ca2+ signaling in astrocytes through reactive oxygen species generated by monoamine oxidase. $J$ Biol Chem; DOI: 10.1074/jbc.M110.111450.

Wallraff A, Köhling R, Heinemann U, Theis M, Willecke K \& Steinhäuser C (2006). The impact of astrocytic gap junctional coupling on potassium buffering in the hippocampus. J Neurosci 26, 5438-5447.

Wang Fushun, Smith, Nathan a, Xu Q, Fujita T, Baba A, Matsuda T, Takano T, Bekar L \& Nedergaard M (2012). Astrocytes modulate neural network activity by $\mathrm{Ca} 2+$ dependent uptake of extracellular K+. Sci Signal 5, 1-15.

Webster HH \& Jones BE (1988). Neurotoxic lesions of the dorsolateral pontomesencephalic tegmentum-cholinergic cell area in the cat. II. Effects upon sleep-waking states. Brain Res; DOI: 10.1016/0006-8993(88)90471-4.

Wei X, Ma T, Cheng Y, Huang CCY, Wang X, Lu J \& Wang J (2018). Dopamine D1 or D2 receptor-expressing neurons in the central nervous system. Addict Biol; DOI: 10.1111/adb.12512.

Xu J, Song D, Bai Q, Cai L, Hertz L \& Peng L (2014). Basic mechanism leading to stimulation of glycogenolysis by isoproterenol, EGF, elevated extracellular K+concentrations, or GABA. Neurochem Res; DOI: 10.1007/s11064-014-1244-z.

Zanassi P, Paolillo M, Montecucco A, Avvedimento E V. \& Schinelli S (1999). Pharmacological and molecular evidence for dopamine D1 receptor expression by striatal astrocytes in culture. J Neurosci Res; DOI: 10.1002/(SICI)10974547(19991115)58:4<544::AID-JNR7>3.0.CO;2-9. 


\section{ADDITIONAL INFORMATION}

Conflict of interest: The authors declare that they have no conflict of interest.

Author Contributions Statement:YB conceived the project. YB, JWM, YBA and ABS designed the experiments. ABS and OK performed and analysed the electrophysiological recordings. All authors wrote and approved the paper.

Acknowledgments: We thank Dr. Sindy Kueh for technical assistance. This study was supported by IPRA to ABS and the Ainsworth medical research innovation fund awarded to YB and JWM.

\section{TABLES}

Table 1. The impact of 5-HT on the $\mathrm{K}$ + clearance rate. Average values of the $[\mathrm{K}+]_{\mathrm{o}}$ clearance rate $(90-10 \%)$, amplitude, rise time (10-90\%) and top peak area (10\%) at all concentrations tested, before and after the application of 5-HT or 5-HT + TTX. Data is reported as mean \pm S.E.M.

\begin{tabular}{|c|c|c|c|c|c|}
\hline$\left[\mathbf{K}_{+}\right]_{\mathbf{o}}$ & Condition & $\begin{array}{c}\text { Clearance } \\
\text { rate }(\mathrm{mM} / \mathrm{sec})\end{array}$ & $\begin{array}{c}\text { Amplitude } \\
(\mathbf{m M})\end{array}$ & $\begin{array}{c}\text { Rise time } \\
\quad(\mathrm{sec})\end{array}$ & $\begin{array}{l}\text { Peak area } \\
\text { (mMxsec) }\end{array}$ \\
\hline $30 \mathrm{mM}$ & $\mathrm{aCSF}$ & $2.04 \pm 0.20$ & $6.40 \pm 0.53$ & $0.32 \pm 0.02$ & $1.25 \pm 0.08$ \\
\hline $15 \mathrm{mM}$ & $\mathrm{aCSF}$ & $0.84 \pm 0.06$ & $2.76 \pm 0.16$ & $0.34 \pm 0.01$ & $0.66 \pm 0.04$ \\
\hline $5 \mathrm{mM}$ & $\mathrm{aCSF}$ & $0.37 \pm 0.03$ & $1.07 \pm 0.21$ & $0.28 \pm 0.03$ & $0.25 \pm 0.02$ \\
\hline $30 \mathrm{mM}$ & 5-HT & $1.33 \pm 0.14$ & $6.64 \pm 0.74$ & $0.34 \pm 0.02$ & $1.43 \pm 0.08$ \\
\hline $15 \mathrm{mM}$ & 5-HT & $0.82 \pm 0.05$ & $2.73 \pm 0.22$ & $0.34 \pm 0.02$ & $0.63 \pm 0.05$ \\
\hline $5 \mathrm{mM}$ & 5-HT & $0.34 \pm 0.04$ & $0.98 \pm 0.03$ & $0.27 \pm 0.03$ & $0.26 \pm 0.04$ \\
\hline $30 \mathrm{mM}$ & 5-HT+TTX & $1.29 \pm 0.11$ & $6.63 \pm 0.61$ & $0.33 \pm 0.02$ & $1.40 \pm 0.06$ \\
\hline $15 \mathrm{mM}$ & 5-HT+TTX & $0.79 \pm 0.05$ & $2.69 \pm 0.19$ & $0.33 \pm 0.02$ & $0.67 \pm 0.04$ \\
\hline $5 \mathrm{mM}$ & 5-HT+TTX & $0.39 \pm 0.04$ & $0.99 \pm 0.05$ & $0.27 \pm 0.04$ & $0.25 \pm 0.03$ \\
\hline
\end{tabular}


Table 2. The impact of DA on the $K+$ clearance rate. Average values of the $\left[K_{+}\right]_{0}$ clearance rate $(90-10 \%)$, amplitude, rise time (10-90\%) and top peak area (10\%) at all concentrations tested, before and after the application of DA or DA + TTX. Data is reported as mean \pm S.E.M.

\begin{tabular}{lccccc}
\hline$[\mathbf{K}+]_{\mathbf{o}}$ & Condition & $\begin{array}{c}\text { Clearance rate } \\
(\mathbf{m M} / \mathbf{s e c})\end{array}$ & $\begin{array}{c}\text { Amplitude } \\
(\mathbf{m M})\end{array}$ & $\begin{array}{c}\text { Rise time } \\
(\mathbf{s e c})\end{array}$ & $\begin{array}{c}\text { Peak area } \\
(\mathbf{m M x s e c})\end{array}$ \\
\hline $\mathbf{3 0} \mathbf{~ m M}$ & aCSF & $2.46 \pm 0.28$ & $7.51 \pm 1.05$ & $0.27 \pm 0.03$ & $1.96 \pm 0.15$ \\
$\mathbf{1 5} \mathbf{~} \mathbf{M}$ & aCSF & $1.60 \pm 0.25$ & $4.24 \pm 0.43$ & $0.27 \pm 0.02$ & $0.99 \pm 0.08$ \\
$\mathbf{5} \mathbf{~} \mathbf{M}$ & aCSF & $0.80 \pm 0.11$ & $1.46 \pm 0.16$ & $0.26 \pm 0.02$ & $0.35 \pm 0.02$ \\
\hline $\mathbf{3 0} \mathbf{~} \mathbf{M}$ & DA & $1.61 \pm 0.26$ & $7.32 \pm 0.83$ & $0.28 \pm 0.03$ & $2.41 \pm 0.17$ \\
$\mathbf{1 5} \mathbf{~} \mathbf{M}$ & DA & $1.35 \pm 0.17$ & $4.13 \pm 0.40$ & $0.29 \pm 0.02$ & $1.21 \pm 0.11$ \\
$\mathbf{5} \mathbf{~} \mathbf{M}$ & DA & $0.60 \pm 0.09$ & $1.49 \pm 0.19$ & $0.27 \pm 0.02$ & $0.46 \pm 0.04$ \\
\hline $\mathbf{3 0} \mathbf{~} \mathbf{M}$ & DA+TTX & $1.68 \pm 0.25$ & $7.25 \pm 0.82$ & $0.28 \pm 0.02$ & $2.36 \pm 0.22$ \\
$\mathbf{1 5} \mathbf{~} \mathbf{M}$ & DA+TTX & $1.21 \pm 0.15$ & $4.26 \pm 0.41$ & $0.28 \pm 0.01$ & $1.10 \pm 0.09$ \\
$\mathbf{5} \mathbf{~} \mathbf{M M}$ & DA+TTX & $0.56 \pm 0.08$ & $1.49 \pm 0.16$ & $0.27 \pm 0.01$ & $0.42 \pm 0.04$ \\
\hline
\end{tabular}

Table 3. The impact of $\mathbf{N A}$ on the $\mathrm{K}+$ clearance rate. Average values of the $[\mathrm{K}+]_{\mathrm{o}}$ clearance rate $(90-10 \%)$, amplitude, rise time $(10-90 \%)$ and top peak area $(10 \%)$ at all concentrations tested, before and after the application of NA or NA + TTX. Data is reported as mean \pm S.E.M.

\begin{tabular}{|c|c|c|c|c|c|}
\hline$\left[\mathbf{K}_{+}\right]_{\mathbf{o}}$ & Condition & $\begin{array}{c}\text { Clearance rate } \\
(\mathrm{mM} / \mathrm{sec})\end{array}$ & $\begin{array}{c}\text { Amplitude } \\
(\mathrm{mM})\end{array}$ & $\begin{array}{c}\text { Rise time } \\
\quad(\mathrm{sec})\end{array}$ & $\begin{array}{l}\text { Peak area } \\
(\mathrm{mMxsec})\end{array}$ \\
\hline $30 \mathrm{mM}$ & aCSF & $1.42 \pm 0.14$ & $5.99 \pm 0.26$ & $0.40 \pm 0.02$ & $1.20 \pm 0.08$ \\
\hline $15 \mathrm{mM}$ & $\mathrm{aCSF}$ & $0.87 \pm 0.05$ & $2.56 \pm 0.15$ & $0.35 \pm 0.02$ & $0.54 \pm 0.06$ \\
\hline $5 \mathrm{mM}$ & $\mathrm{aCSF}$ & $0.44 \pm 0.04$ & $0.92 \pm 0.06$ & $0.30 \pm 0.02$ & $0.25 \pm 0.04$ \\
\hline $30 \mathrm{mM}$ & NA & $0.80 \pm 0.06$ & $5.94 \pm 0.45$ & $0.39 \pm 0.03$ & $1.45 \pm 0.07$ \\
\hline $15 \mathrm{mM}$ & NA & $0.70 \pm 0.06$ & $2.52 \pm 0.11$ & $0.36 \pm 0.02$ & $0.78 \pm 0.08$ \\
\hline $5 \mathrm{mM}$ & NA & $0.42 \pm 0.04$ & $0.92 \pm 0.05$ & $0.29 \pm 0.02$ & $0.30 \pm 0.04$ \\
\hline $30 \mathrm{mM}$ & NA+TTX & $0.90 \pm 0.07$ & $5.76 \pm 0.41$ & $0.38 \pm 0.03$ & $1.54 \pm 0.10$ \\
\hline $15 \mathrm{mM}$ & NA+TTX & $0.65 \pm 0.05$ & $2.49 \pm 0.09$ & $0.35 \pm 0.02$ & $0.77 \pm 0.08$ \\
\hline $5 \mathrm{mM}$ & NA+TTX & $0.42 \pm 0.04$ & $0.91 \pm 0.04$ & $0.30 \pm 0.03$ & $0.28 \pm 0.05$ \\
\hline
\end{tabular}


Table 4. The impact of Histamine on the $K_{+}$clearance rate. Average values of the $\left[K_{+}\right]_{0}$ clearance rate $(90-10 \%)$, amplitude, rise time (10-90\%) and top peak area (10\%) at all concentrations tested, before and after the application of Histamine or Histamine + TTX. Data is reported as mean \pm S.E.M.

\begin{tabular}{lccccc}
\hline$[\mathbf{K}+]_{\mathbf{o}}$ & Condition & $\begin{array}{c}\text { Clearance } \\
\text { rate }(\mathbf{m M} / \mathbf{s e c})\end{array}$ & $\begin{array}{c}\text { Amplitude } \\
(\mathbf{m M})\end{array}$ & $\begin{array}{c}\text { Rise time } \\
(\mathbf{s e c})\end{array}$ & $\begin{array}{c}\text { Peak area } \\
(\mathbf{m M x s e c})\end{array}$ \\
\hline $\mathbf{3 0} \mathbf{~} \mathbf{M}$ & aCSF & $2.02 \pm 0.38$ & $6.52 \pm 0.77$ & $0.31 \pm 0.01$ & $0.74 \pm 0.03$ \\
$\mathbf{1 5} \mathbf{~} \mathbf{M}$ & aCSF & $1.12 \pm 0.09$ & $3.50 \pm 0.32$ & $0.28 \pm 0.01$ & $0.51 \pm 0.04$ \\
$\mathbf{5} \mathbf{~} \mathbf{M}$ & aCSF & $0.51 \pm 0.05$ & $0.93 \pm 0.09$ & $0.26 \pm 0.01$ & $0.15 \pm 0.01$ \\
\hline $\mathbf{3 0} \mathbf{~} \mathbf{M}$ & Histamine & $1.15 \pm 0.14$ & $6.63 \pm 0.57$ & $0.32 \pm 0.01$ & $1.04 \pm 0.06$ \\
$\mathbf{1 5} \mathbf{~} \mathbf{M}$ & Histamine & $0.84 \pm 0.08$ & $3.49 \pm 0.56$ & $0.27 \pm 0.01$ & $0.72 \pm 0.04$ \\
$\mathbf{5} \mathbf{~} \mathbf{M}$ & Histamine & $0.30 \pm 0.02$ & $0.93 \pm 0.14$ & $0.25 \pm 0.02$ & $0.19 \pm 0.01$ \\
\hline $\mathbf{3 0} \mathbf{~} \mathbf{M}$ & Histamine+TTX & $1.19 \pm 0.16$ & $6.49 \pm 0.61$ & $0.32 \pm 0.01$ & $1.09 \pm 0.04$ \\
$\mathbf{1 5} \mathbf{~} \mathbf{M}$ & Histamine+TTX & $1.09 \pm 0.12$ & $3.41 \pm 0.54$ & $0.27 \pm 0.02$ & $0.63 \pm 0.05$ \\
$\mathbf{5} \mathbf{~} \mathbf{M}$ & Histamine+TTX & $0.46 \pm 0.03$ & $0.91 \pm 0.07$ & $0.26 \pm 0.01$ & $0.17 \pm 0.01$ \\
\hline
\end{tabular}

Table 5. The impact of Acetylcholine on the $K+$ clearance rate. Average values of the $\left[K_{+}\right]_{0}$ clearance rate $(90-10 \%)$, amplitude, rise time (10-90\%) and top peak area $(10 \%)$ at all concentrations tested, before and after the application of Carbachol or Carbachol + TTX. Data is reported as mean \pm S.E.M.

\begin{tabular}{lccccc}
\hline$\left[\mathbf{K}_{+}\right]_{\mathbf{o}}$ & Condition & $\begin{array}{c}\text { Clearance } \\
\text { rate }(\mathbf{m M} / \mathbf{s e c})\end{array}$ & $\begin{array}{c}\text { Amplitude } \\
(\mathbf{m M})\end{array}$ & $\begin{array}{c}\text { Rise time } \\
(\mathbf{s e c})\end{array}$ & $\begin{array}{c}\text { Peak area } \\
(\mathbf{m M x s e c})\end{array}$ \\
\hline $\mathbf{3 0} \mathbf{~ m M}$ & aCSF & $1.30 \pm 0.12$ & $6.63 \pm 0.4$ & $0.31 \pm 0.02$ & $1.29 \pm 0.07$ \\
$\mathbf{1 5} \mathbf{~ m M}$ & aCSF & $1.02 \pm 0.10$ & $3.26 \pm 0.4$ & $0.27 \pm 0.02$ & $0.83 \pm 0.09$ \\
$\mathbf{5} \mathbf{~ m M}$ & aCSF & $0.52 \pm 0.06$ & $1.34 \pm 0.2$ & $0.22 \pm 0.01$ & $0.26 \pm 0.03$ \\
\hline $\mathbf{3 0} \mathbf{~ m M}$ & Carbachol & $1.36 \pm 0.13$ & $6.58 \pm 0.5$ & $0.31 \pm 0.02$ & $1.28 \pm 0.07$ \\
$\mathbf{1 5} \mathbf{~ m M}$ & Carbachol & $0.97 \pm 0.09$ & $3.28 \pm 0.4$ & $0.27 \pm 0.01$ & $0.77 \pm 0.07$ \\
$\mathbf{5} \mathbf{~ m M}$ & Carbachol & $0.51 \pm 0.07$ & $1.36 \pm 0.2$ & $0.23 \pm 0.01$ & $0.26 \pm 0.02$ \\
\hline $\mathbf{3 0} \mathbf{~ m M}$ & Carbachol+TTX & $1.37 \pm 0.11$ & $6.79 \pm 0.6$ & $0.30 \pm 0.02$ & $1.22 \pm 0.08$ \\
$\mathbf{1 5} \mathbf{~ m M}$ & Carbachol+TTX & $1.06 \pm 0.10$ & $3.27 \pm 0.3$ & $0.26 \pm 0.01$ & $0.81 \pm 0.04$ \\
$\mathbf{5} \mathbf{~ m M}$ & Carbachol+TTX & $0.54 \pm 0.07$ & $1.39 \pm 0.2$ & $0.23 \pm 0.01$ & $0.25 \pm 0.01$
\end{tabular}




\section{FIGURES \& LEGENDS}

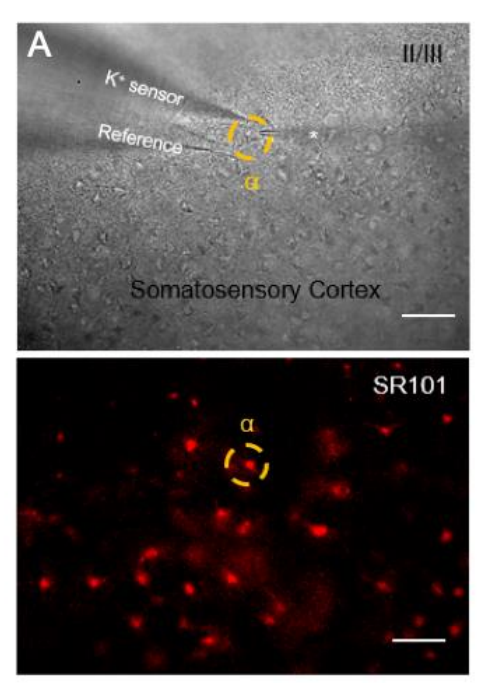

C

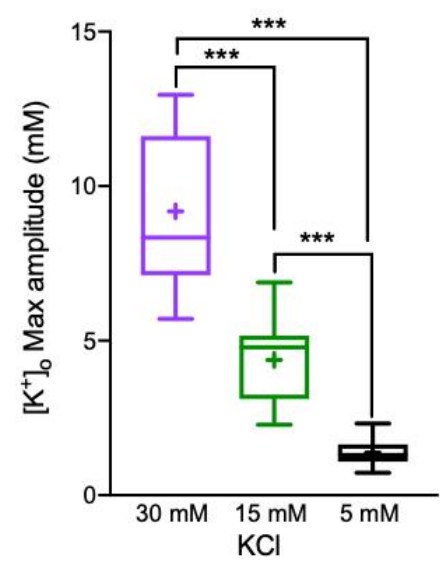

B

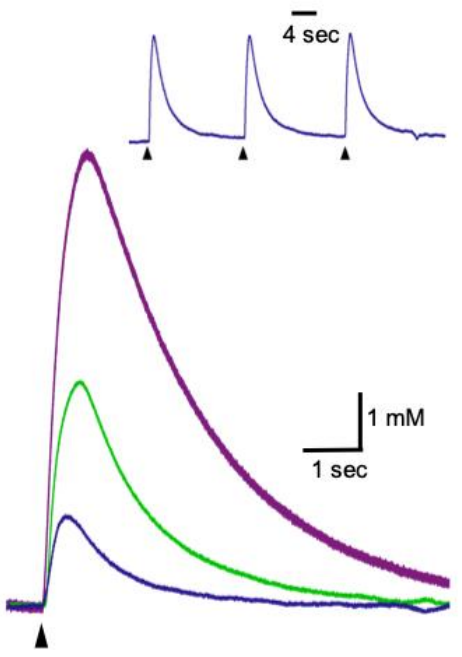

D

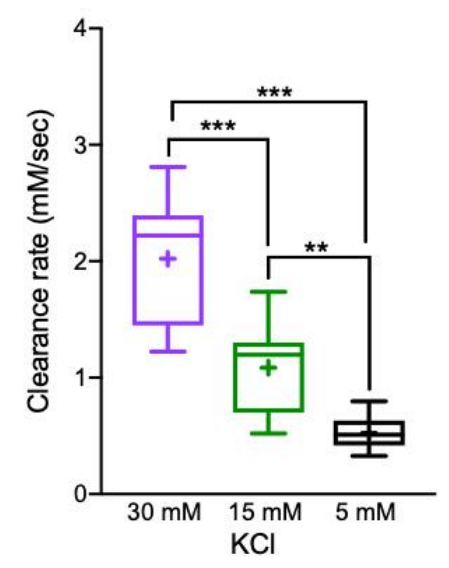

Figure 1. Measuring K+ clearance in acute brain slices. A) Top - DIC image of a brain slice depicting the the $\mathrm{K}+$ recording electrode together with the $\mathrm{KCl}$ puffing electrode in layers $2 / 3$ of the somatosensory cortex (scale bar - $50 \mu \mathrm{m}$ ). Bottom - fluorescence image of the same region depicting astrocytes stained with SR101; yellow circle surrounds to an astrocyte nearby the recording electrode (astrocyte $\propto$ ). B) Top- sample traces of $[\mathrm{K}+]_{0}$ recordings following repetitive stimulation with $5 \mathrm{mM} \mathrm{KCl}$, arrows indicate the time of $\mathrm{KCl}$ application. Bottomaverage traces of 3 repetitive $[\mathrm{K}+]_{\mathrm{o}}$ recordings depicting the $\mathrm{K}+$ clearance time course following local application of $30 \mathrm{mM}$ (purple), $15 \mathrm{mM}$ (green) and $5 \mathrm{mM}$ (blue) $\mathrm{KCl}$ puffs. C,D) Box plots depicting the maximal amplitude (C) and clearance rate (D) following local application of 5,15 , and $30 \mathrm{mM} \mathrm{KCl}$. The box upper and lower limits are the 25 th and 75 th quartiles, respectively. The whiskers depicting the lowest and highest data points, while the + sign represents the mean and the horizontal line through the box is the median. 

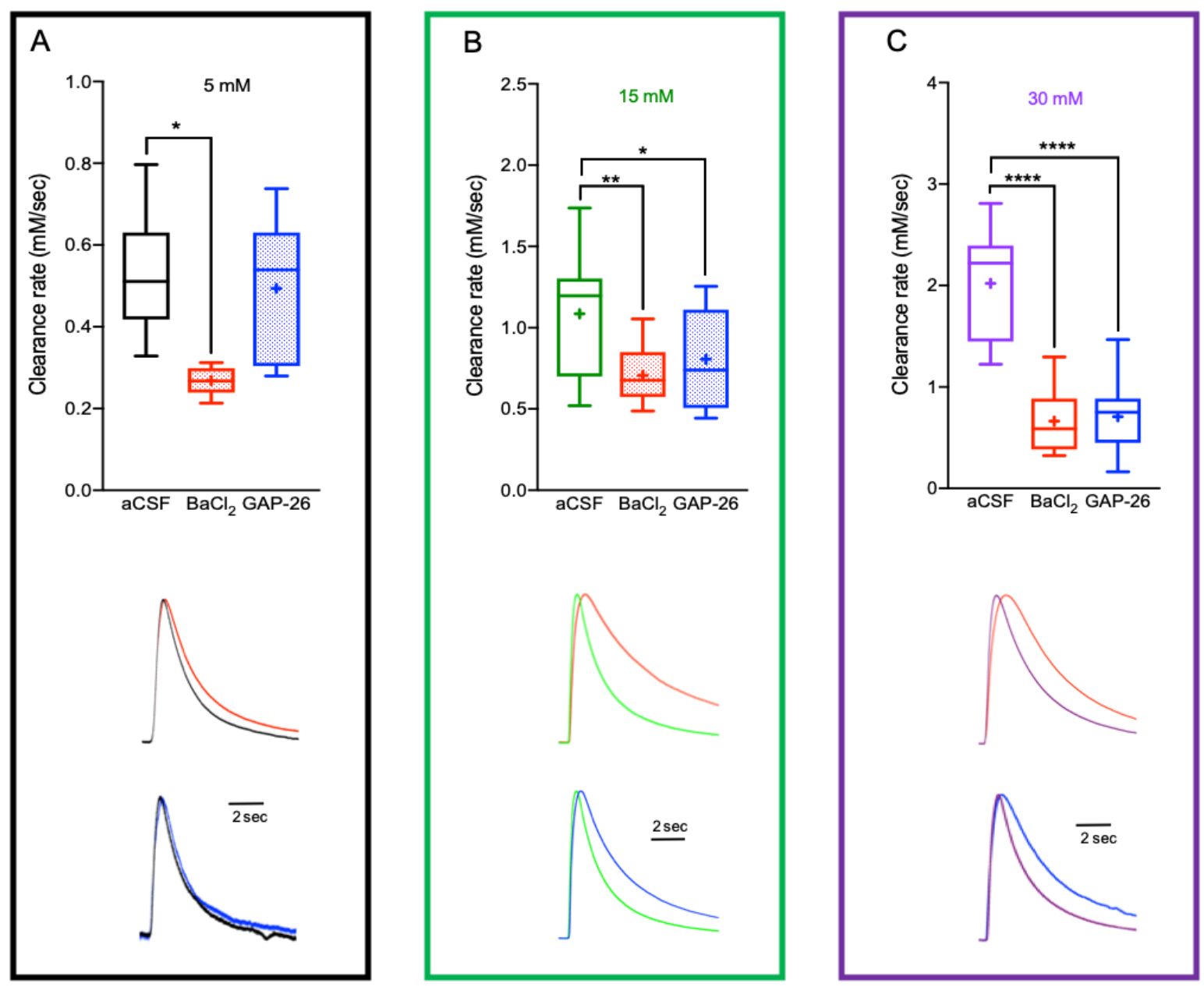

Figure 2. Impaired astrocytic $\mathbf{K}+$ clearance affect [ $\mathbf{K}+]_{\mathbf{o}}$ dynamics. A-C) Box plots depicting the average $\mathrm{K}+$ clearance rate following local application of $5 \mathrm{mM}(\mathrm{A}) 15 \mathrm{mM}(\mathrm{B})$, and 30 (C) $\mathrm{mM} \mathrm{KCl}$, under control conditions (aCSF), reduced Kir4.1 activity (red) or impaired astrocytic GJ conductance (blue). Bottom- sample traces of $[\mathrm{K}+]_{\mathrm{o}}$ recording (normalised to the peak amplitude) under control and impaired clearance conditions; red traces- with $\mathrm{BaCl}_{2}$; blue traces- with Gap-26/27 mixture. Control traces are colour coded as per their concentration (black-5 mM, green-15 mM and purple-30 mM). Box plots definition are the same as in Fig. 1. ${ }^{*} \mathrm{p}<0.05 ;{ }^{* *} \mathrm{p}<0.01 ; * * \mathrm{p}<0.0001$; two-way ANOVA. 


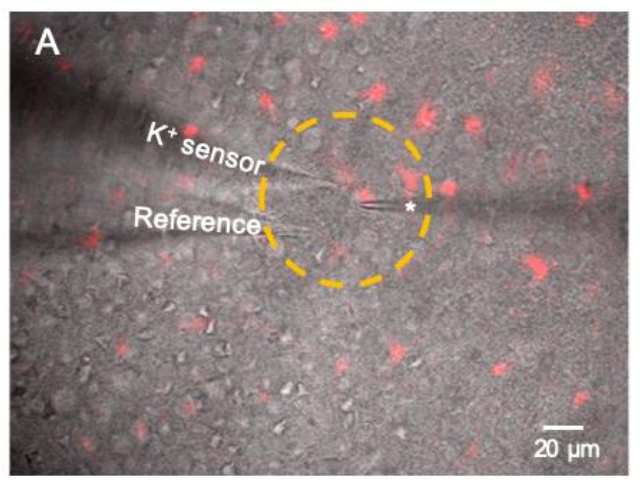

D

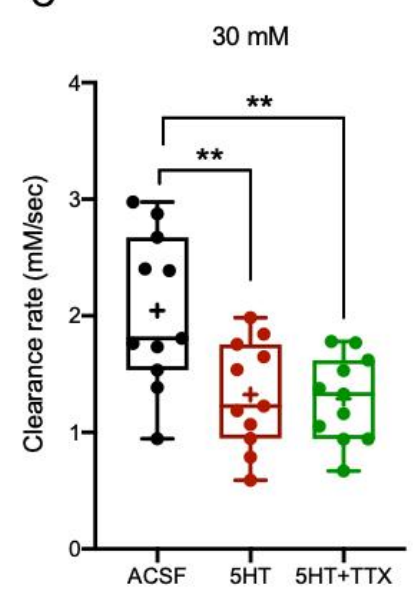

B

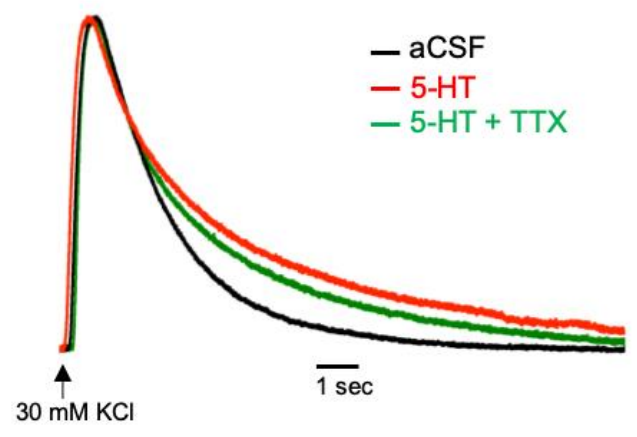

$E$

$15 \mathrm{mM}$

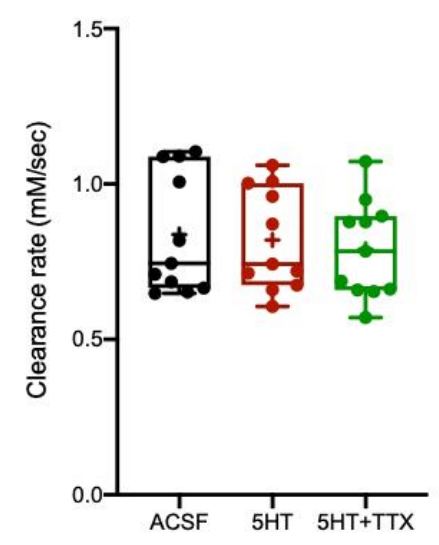

$5 \mathrm{mM}$

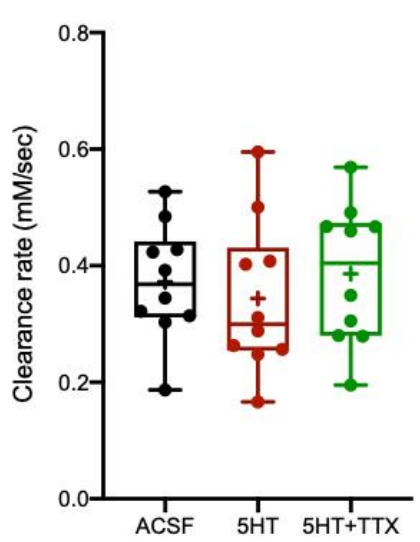

Figure 3. The impact of 5-HT on the $\mathrm{K}+$ clearance rate and astrocytic Ca2+ signalling. A) Merged image of DIC (grey) and SR-101 (red) staining depicting the experimental setup, including the $\mathrm{K}+$ recording electrode, the $\mathrm{KCl}$ puffing electrode $\left(^{*}\right)$ and the photo-activated region (yellow circle, $360 \mathrm{~nm}$ for 1 second prior to local application of $\mathrm{KCl}$ ) used for application of the neuromodulators Serotonin (NPEC-caged-Serotonin, $30 \mu \mathrm{M}$ ) and Dopamine (NPEC-caged-Dopamine, $10 \mu \mathrm{M}$ ). B) Sample traces of $\left[\mathrm{K}_{+}\right]_{\text {o }}$ recordings depicting the $\mathrm{K}_{+}$ clearance time course following local application of $30 \mathrm{mM} \mathrm{KCl}$ (arrow), before (aCSF, black) and after focal photolysis of $30 \mu \mathrm{M}$ caged Serotonin (5-HT, red) or $30 \mu \mathrm{M}$ caged 5-HT with 1 $\mu \mathrm{M}$ TTX (green). C-E) Box plots depicting the $\mathrm{K}+$ clearance rate following local application of $30 \mathrm{mM}(\mathrm{C}), 15 \mathrm{mM}$ (D) and $5 \mathrm{mM}$ (E) $\mathrm{KCl}$ before (black dots) and after photolysis of 5-HT (red dots ) or 5-HT + TTX (green dots). Box plot definitions is the same as in Fig. 1. * $p<0.05$; $* * p<0.01 ; * * * p<0.0001$ 
A

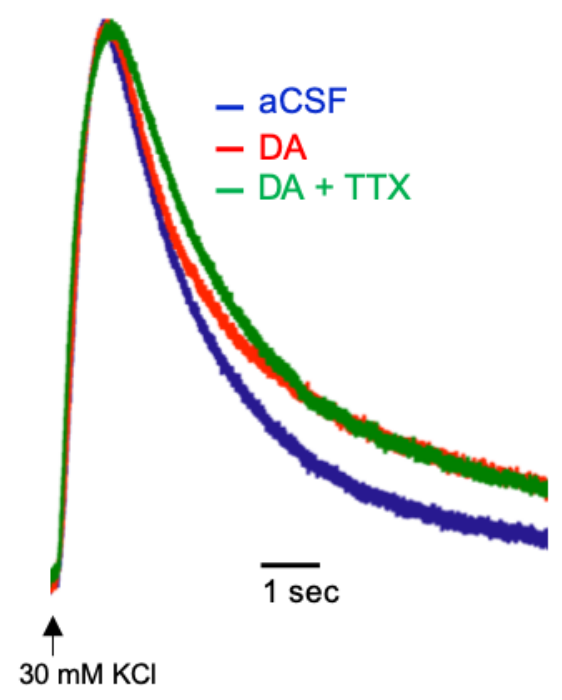

C

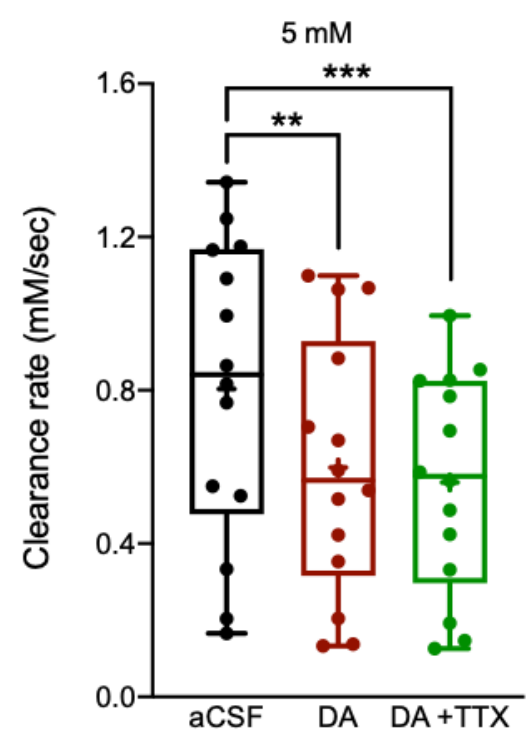

B

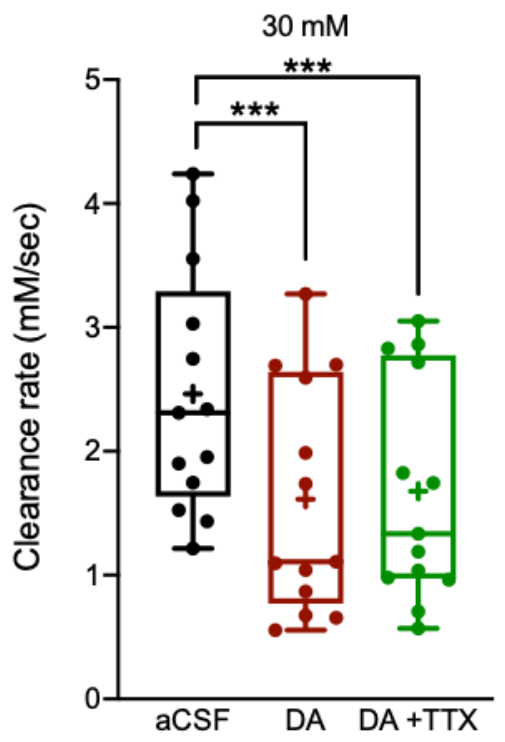

D

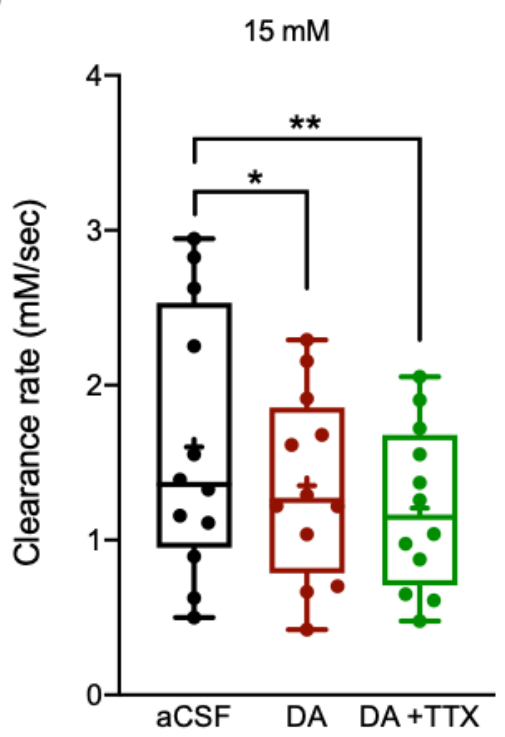

Figure 4 The impact of DA on the $\mathrm{K}+$ clearance rate and astrocytic $\mathrm{Ca}+$ signalling. A) Sample traces of $[\mathrm{K}+]_{0}$ recordings depicting the $\mathrm{K}+$ clearance time course following local application of $30 \mathrm{mM} \mathrm{KCl}$ (arrow), before (aCSF, black) and after focal photolysis of $30 \mu \mathrm{M}$ caged Dopamine (DA, red) or $30 \mu \mathrm{M}$ caged DA with $1 \mu \mathrm{M}$ TTX (green). B-D) Box plots depicting the $\mathrm{K}+$ clearance rate following local application of $\mathrm{KCl}$ at $30 \mathrm{mM}(\mathrm{B}), 15 \mathrm{mM}$ (C) and $5 \mathrm{mM}(\mathrm{D})$, before (aCSF, black dots) and after DA uncaging without (red dots) or with TTX (green dots). Box plot definitions is the same as in Fig. 1. ${ }^{*} \mathrm{p}<0.05 ; * * \mathrm{p}<0.01 ; * * * \mathrm{p}<$ 0.0001 
A

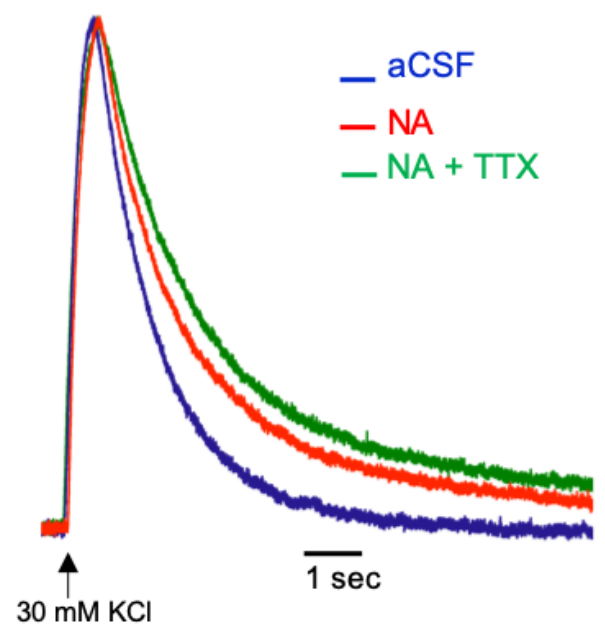

C

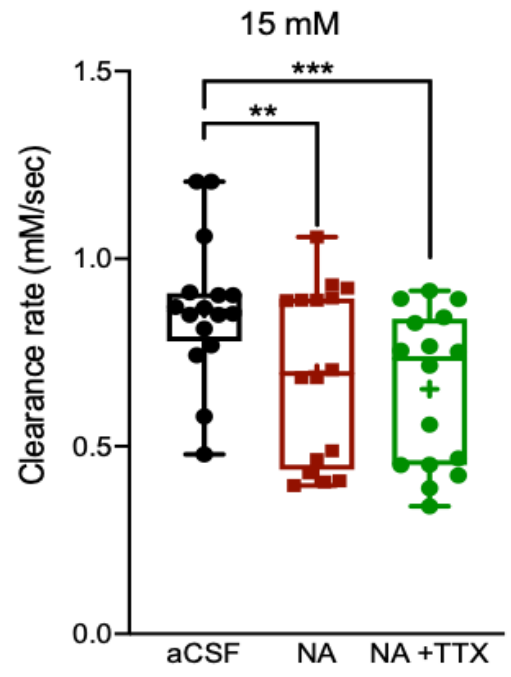

B

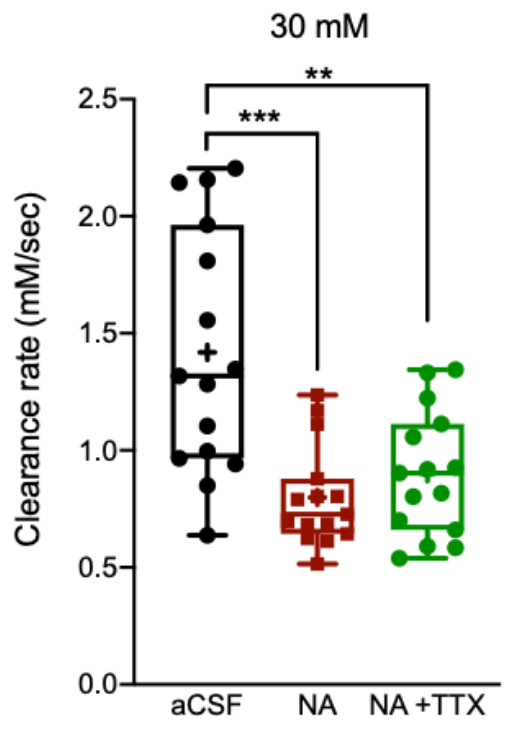

D

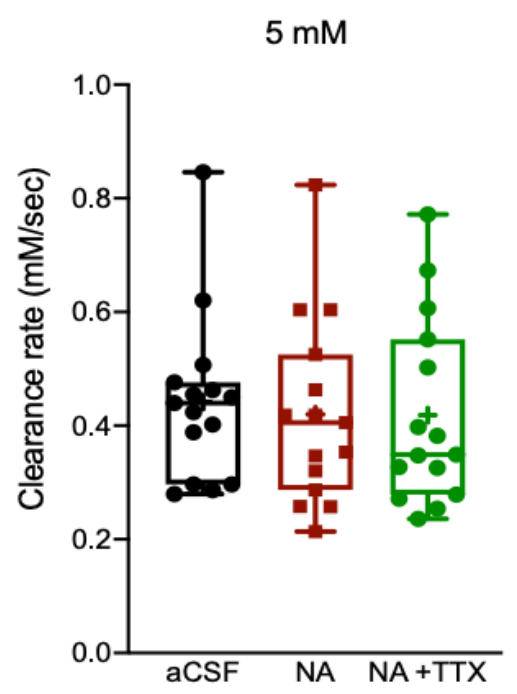

Figure 5. The impact of NA on the $\mathrm{K}+$ clearance rate and astrocytic Ca2+ signalling. A) Sample traces of $[\mathrm{K}+]_{0}$ recordings depicting the $\mathrm{K}+$ clearance time course following local application of $30 \mathrm{mM} \mathrm{KCl}$ (arrow), before (aCSF, blue) and after application of Noradrenaline bitartrate (40 $\mu \mathrm{M}, \mathrm{NA}$, red) or NA with $1 \mu \mathrm{M}$ TTX (green). B-D) Box plots depicting the $\mathrm{K}_{+}$ clearance rate following local application of $\mathrm{KCl}$ at $30 \mathrm{mM}(\mathrm{B}), 15 \mathrm{mM}$ (C) and $5 \mathrm{mM}$ (D), before (aCSF, black dots) and after bath application of NA without (red dots) or with TTX (green dots). Box plot definitions is the same as in Fig. 1. ${ }^{*} \mathrm{p}<0.05 ; * * \mathrm{p}<0.01 ; * * * \mathrm{p}<0.0001$ 
A

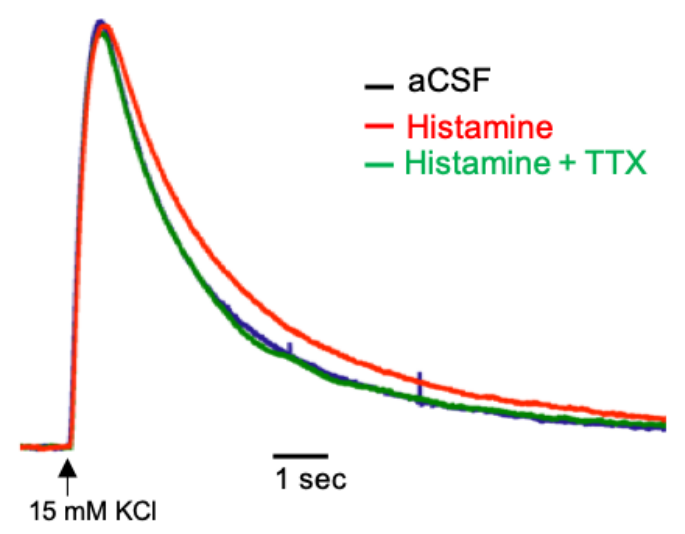

C

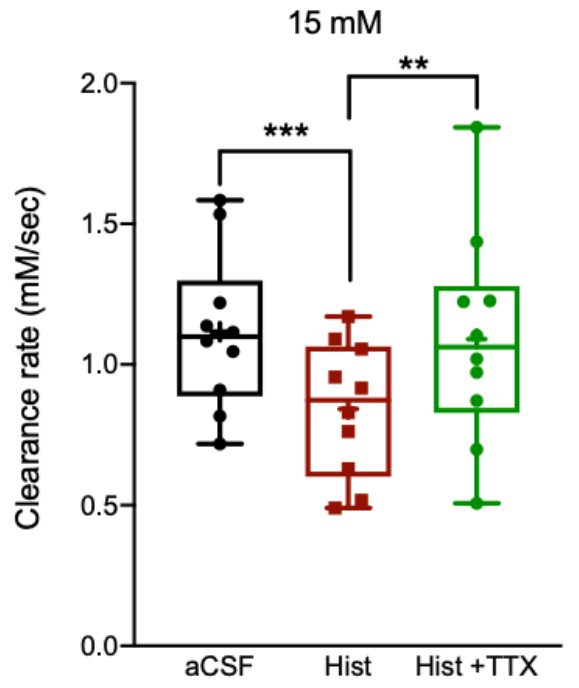

B

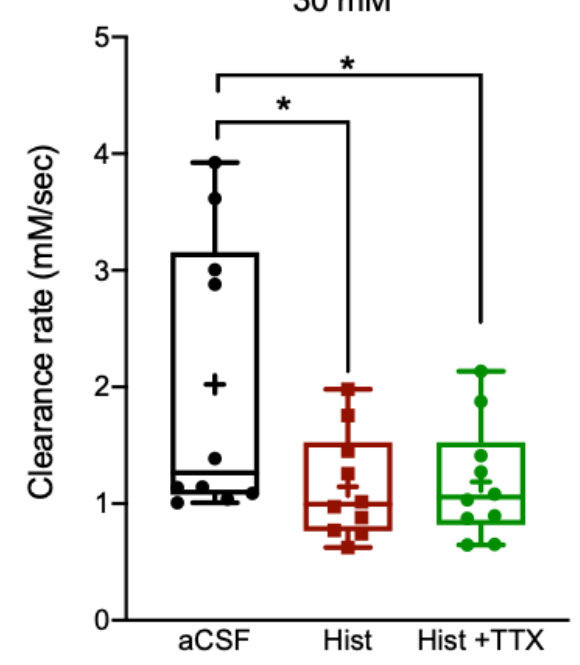

D

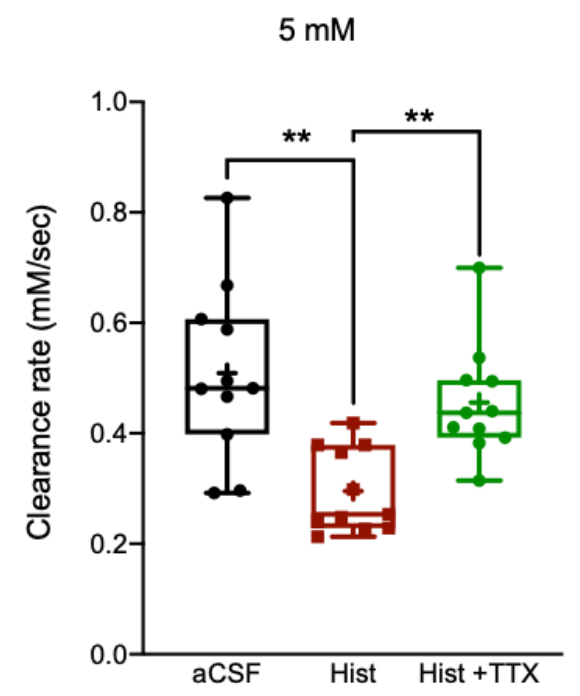

Figure 6. The impact of Histamine on the $\mathrm{K}+$ clearance rate and astrocytic $\mathrm{Ca}+$ signalling.

A) Sample traces of $[\mathrm{K}+]_{0}$ recordings depicting the $\mathrm{K}+$ clearance time course following local application of $15 \mathrm{mM} \mathrm{KCl}$ (arrow), before (aCSF, black) and after bath application of Histamine dihydrochloride (50 $\mu \mathrm{M}$, red) or Histamine with $1 \mu \mathrm{M}$ TTX (green). B-D) Box plots depicting the $\mathrm{K}+$ clearance rate following local application of $\mathrm{KCl}$ at $30 \mathrm{mM}$ (A), $15 \mathrm{mM}$ (B) and $5 \mathrm{mM}(\mathrm{C})$, before (aCSF, black dots) and after bath application of Histamine dihydrochloride $(50 \mu \mathrm{M})$ without (red dots) or with TTX (green dots). Box plot definitions is the same as in Fig. $1 .{ }^{*} \mathrm{p}<0.05 ; * * \mathrm{p}<0.01 ; * * \mathrm{p}<0.0001$ 
A

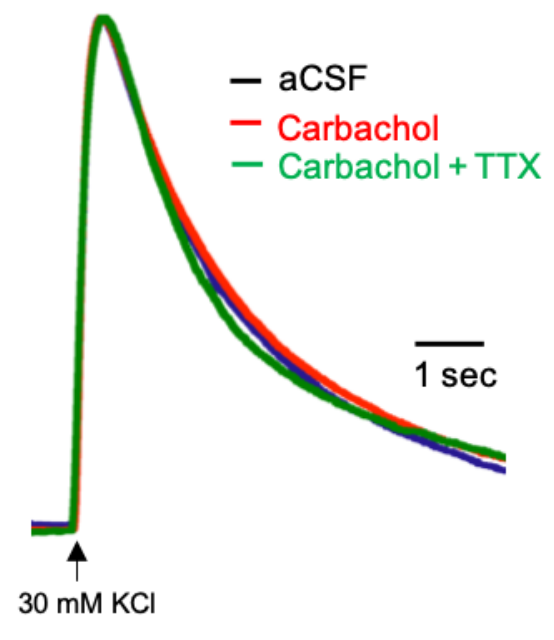

C

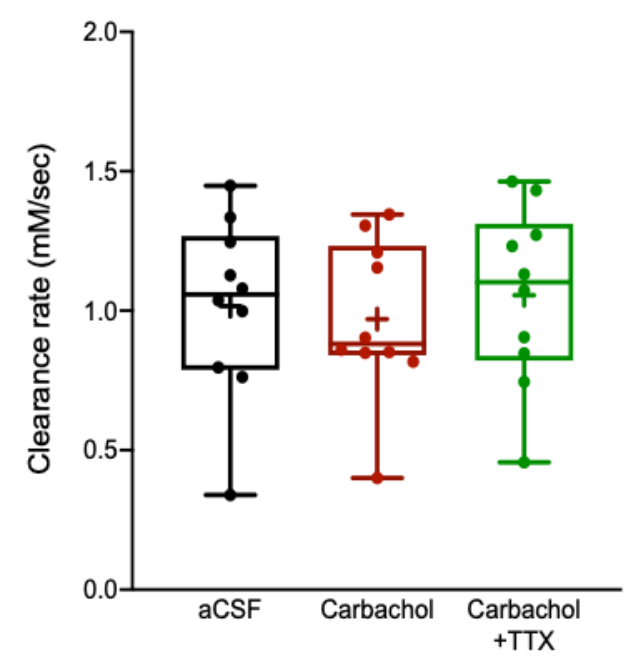

B

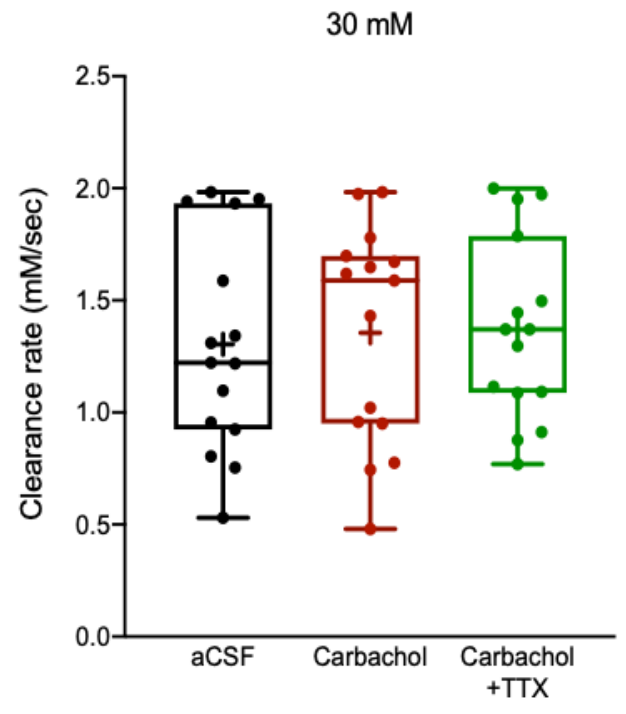

D

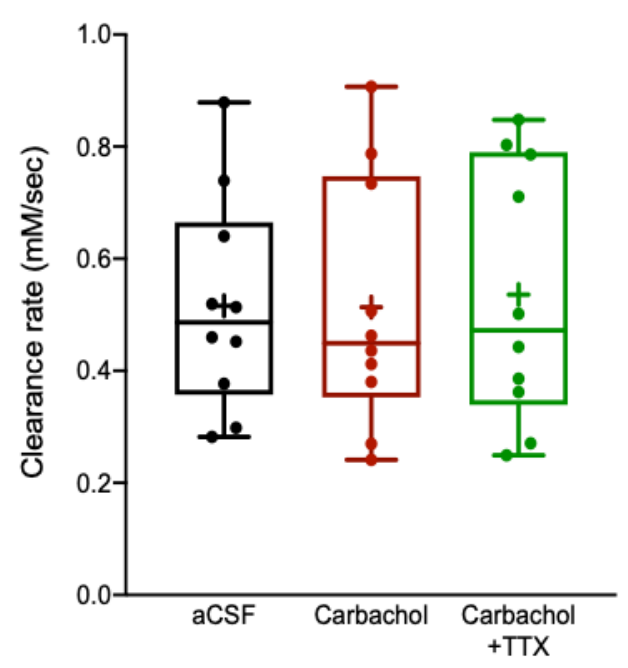

Figure 7. The impact of Carbachol on the $\mathrm{K}+$ clearance rate and astrocytic Ca2+ signalling.

A) Sample traces of $\left[\mathrm{K}_{+}\right]_{\mathrm{o}}$ recordings depicting the $\mathrm{K}+$ clearance time course following local application of $30 \mathrm{mM} \mathrm{KCl} \mathrm{(arrow),} \mathrm{before} \mathrm{(aCSF,} \mathrm{blue)} \mathrm{and} \mathrm{after} \mathrm{application} \mathrm{of} \mathrm{Carbachol} \mathrm{(100}$ $\mu \mathrm{M}$, red) or Carbachol with $1 \mu \mathrm{M}$ TTX (green). B-D) Box plots depicting the $\mathrm{K}+$ clearance rate following local application of $\mathrm{KCl}$ at $30 \mathrm{mM}(\mathrm{B}), 15 \mathrm{mM}(\mathrm{C})$ and $5 \mathrm{mM}(\mathrm{D})$, before (aCSF, black dots) and after bath application of Carbachol $(100 \mu \mathrm{M})$ without (red dots) or with TTX (green dots). Box plot definitions is the same as in Fig. 1. 